\title{
Fertile, plump, and strong: The social construction of the female body in low-income Cairo [Arabic]
}

Farha Ghannam

Follow this and additional works at: https://knowledgecommons.popcouncil.org/departments_sbsr-pgy How does access to this work benefit you? Let us know!

\section{Recommended Citation}

Ghannam, Farha. 1997. "Fertile, plump, and strong: The social construction of the female body in lowincome Cairo [in Arabic]," Monographs in Reproductive Health. Cairo: Reproductive Health Working Group. 


\title{
خصبة، وممتلئة، وقوية:
}

البناء الاجتماعي لجسد المرأة فى المناطق ذات الاخل المنخفض من

(القاهزة

\section{" فـرحسة غـــــام_" Farha Ghannam}

\author{
سلسلة دراسات فى الصحة الإجابية \\ رقم 3 \\ 1997
}

Reproductive Health Working Group مجلس السكان العل فى الصحة الإجابية
Population Council

The Population Council Regional المكتب الإقليمي لغرب آسيا وشمال أفريقيا Office for West Asia and North Africa 


\section{تمهيد \\ دراسات فى الصحة الإنجابية}

تستهدف سلسلة در اسات Monographs فى الصحة الإنجابية اقتسام البحوث - التي يجريها أعضاء مجموعة العمل حول الصحة الإنجابية - مع صانعى السياسات ومديرى البرامج

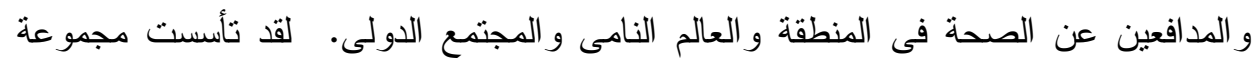
عمل الصحة الإنجابية عام 1988، كجزء من برنامج خاص يتعلق بصحة النساء و الأطفال في ولي

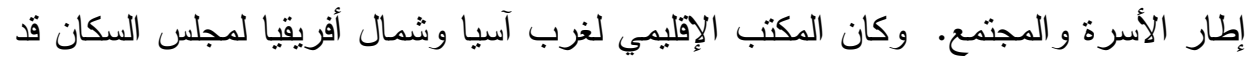
قام بإطلاق هذا البرنامج؛ وتتضمن مجموعة العمل حول الصحة الإنجابية متخصصين في الإني الأنثروبولوجيا، والإحصاء الحيوى، وعلم السكان، و الطب، و الصحة العامة، وعلم الاجتماع؛ و هم ينتمون إلى بلدان متعددة من المنطقة.

لقد حددت مجموعة العمل حول الصحة الإنجابية ثلاث قضايا أساسية تم اعتبارها قضايا

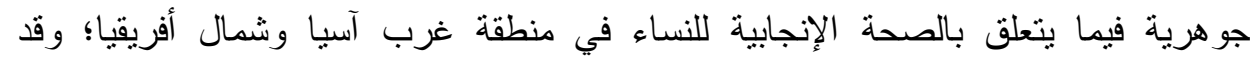

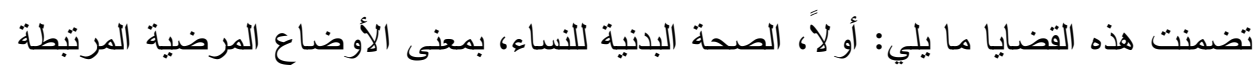

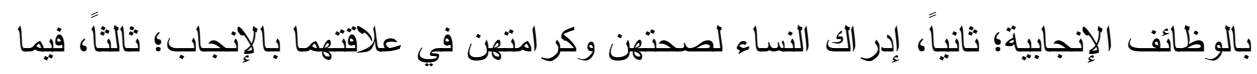
يتعلق بالخدمات الصحية، نوعية الخدمات التي تقدم للنساء في مجال الصحة الإنجابية. وقاء وقداء قامت مجموعة العمل منذ عام 1989 بإجر اء الدراسات التي تنتاول هذه القضايا في بلدان

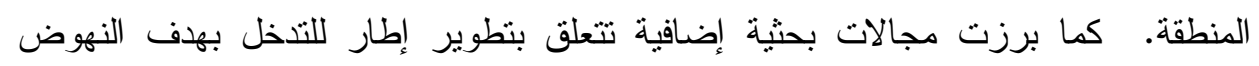

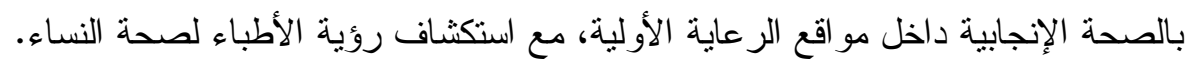

تعد سلسلة سياسات الصحة الإنجابية وسلسلة در اسات الصحة الإنجابية مجمو عتان متكاملتان،

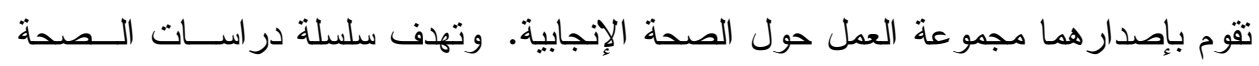

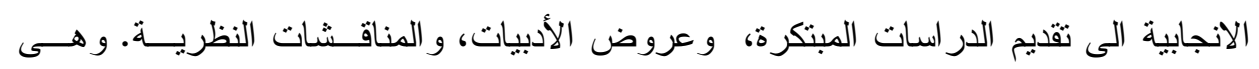

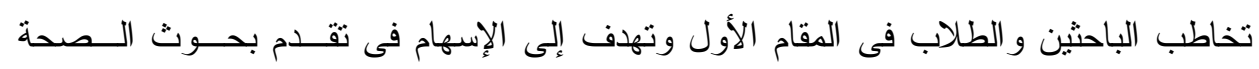

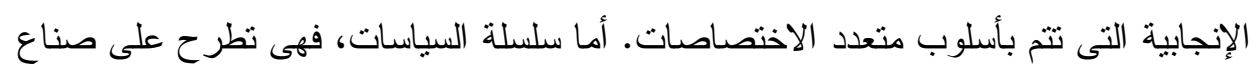
السياسات، ومديرى البر امج، و المهتمين بشئون الصحة، إطار ات، و أساليب، و وأدلة من منظور

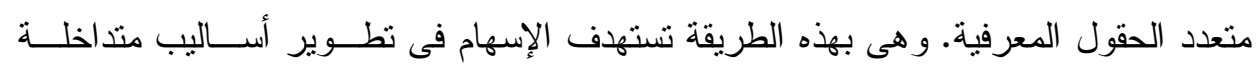
المعارف لتكون أكثر قدرة على تلبية الاحتياجات الصحية لنساء الدول النامية. 
أصبح جسم الإنسان خلال العقدين الأخيرين مركز الاهتمام فى نطاق واسع من من الدراسات

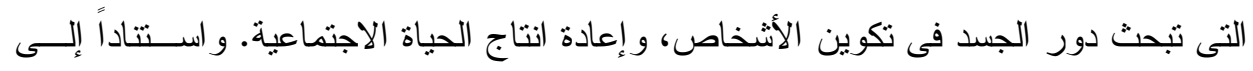

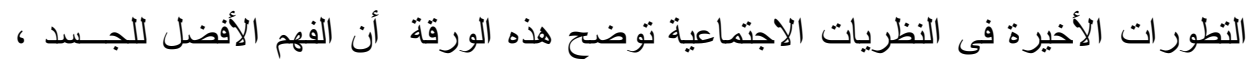

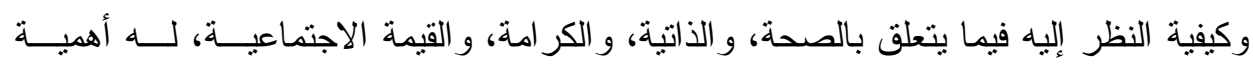

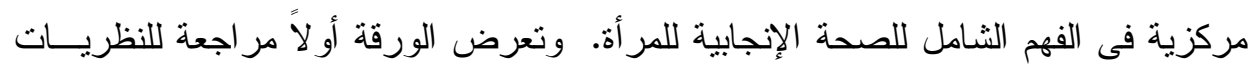

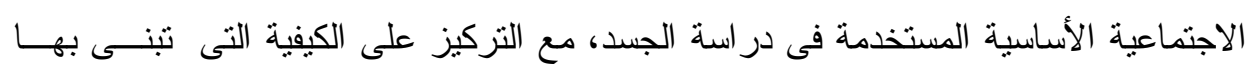

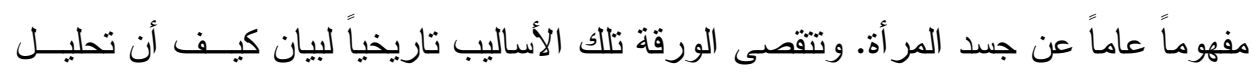

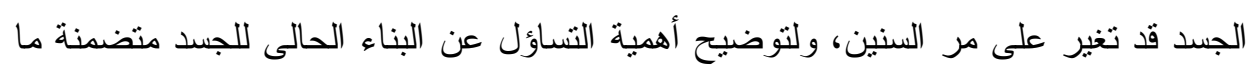

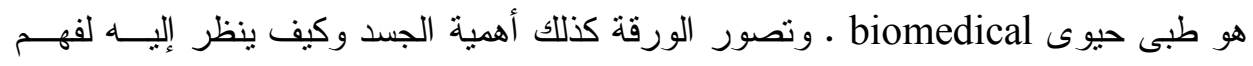

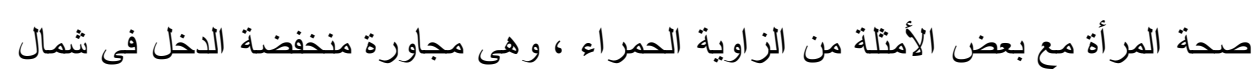

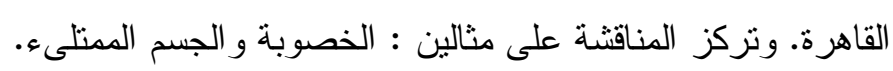

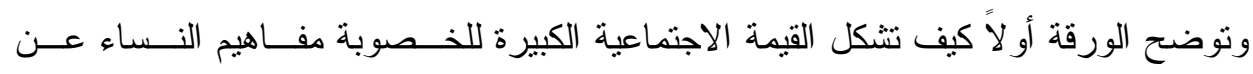

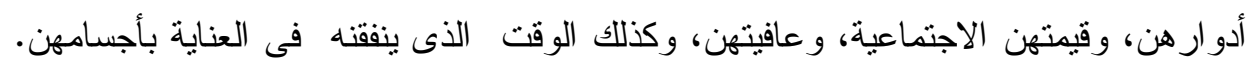

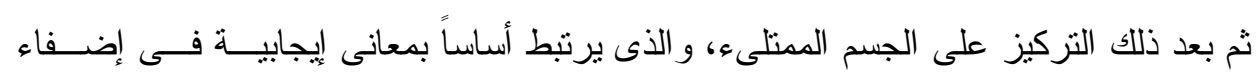

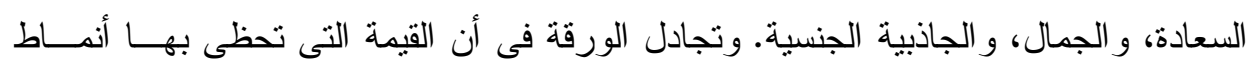

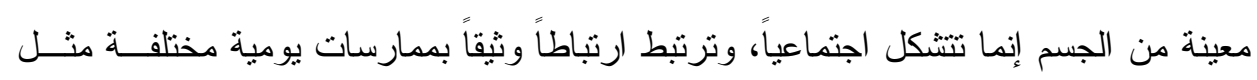

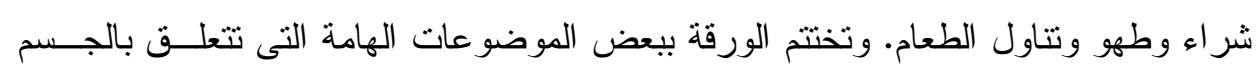
وتحتاج إلى المزيد من البحث مستقبلاً.

\section{" فرحة غنــام Farha Ghannam "}


تعتبر "زهرة" نفسها شابة محظوظة، فقد صـارت حاملاً فور زواجها. ولـيس هـــا بــالأمر

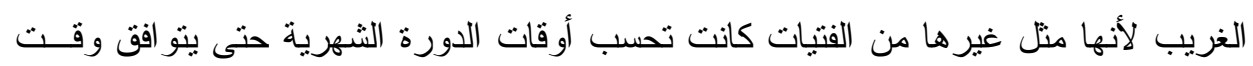

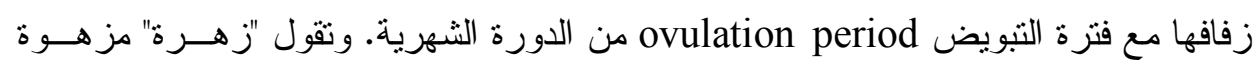

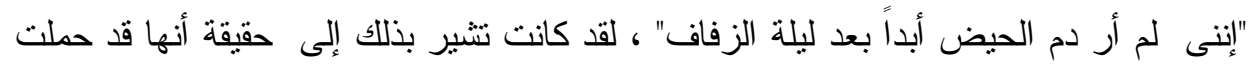

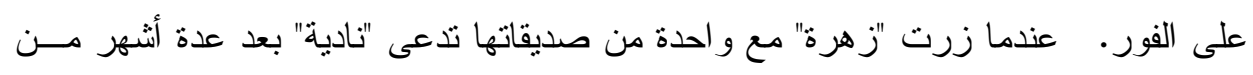

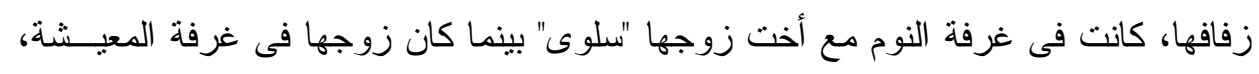

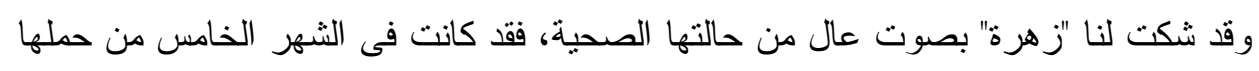

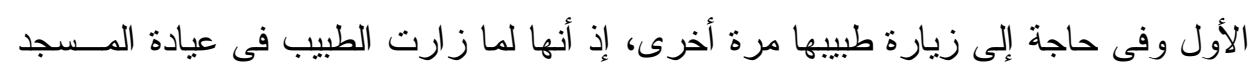

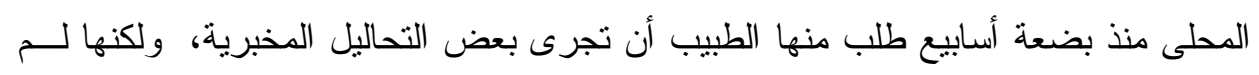

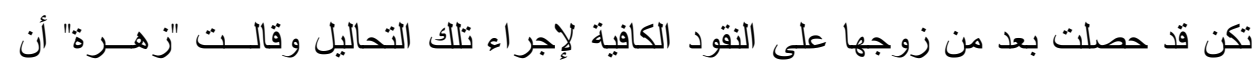

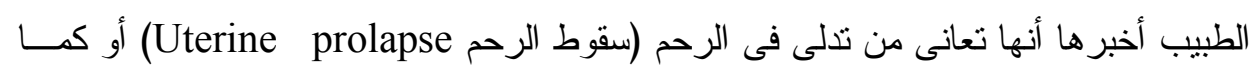
عبرت هى "الرحم و اطى" ، وقالت أخت زوجها "سلوى" أنها تعانى من نفس المشكلة ، و وأنها

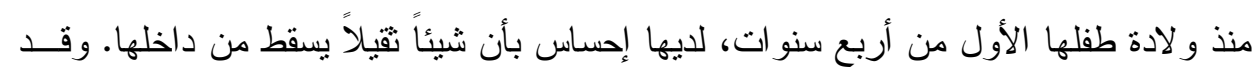

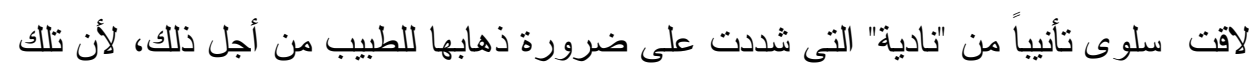

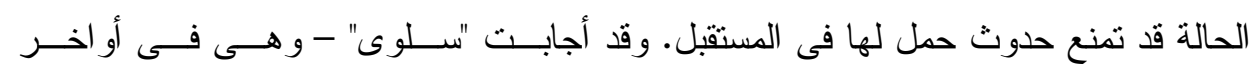

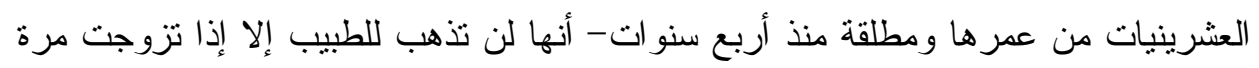

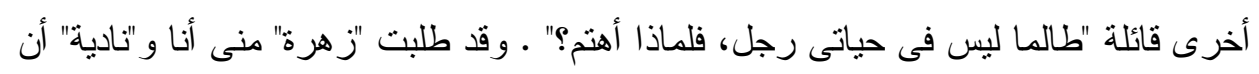

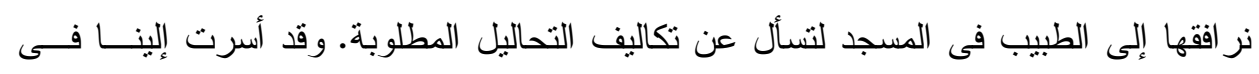
الطريق أنها فى الحقيقة لا تعانى من سقوط الرحم كما قالت من قبل بل من إفراز ات غزيرة.

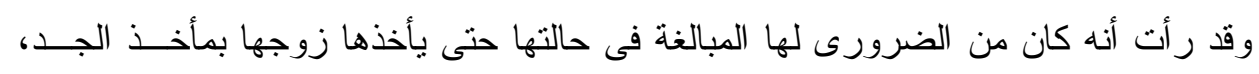
ويعطيها النقود اللازمة للتحاليل. وقد أوضحت لنا أنها تفضل الذهاب إلى عيادة المسجد بدلاً

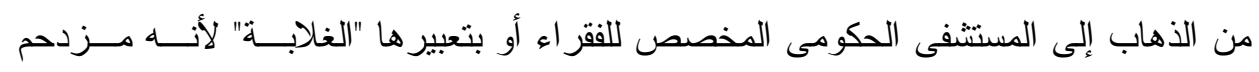

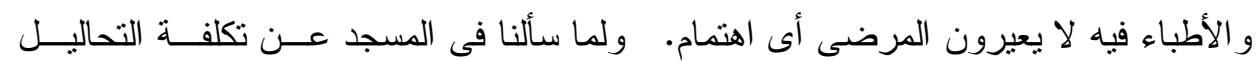

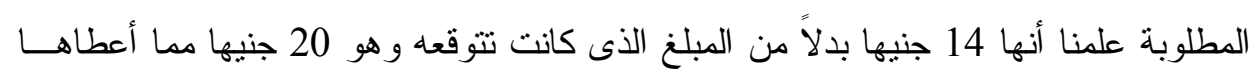

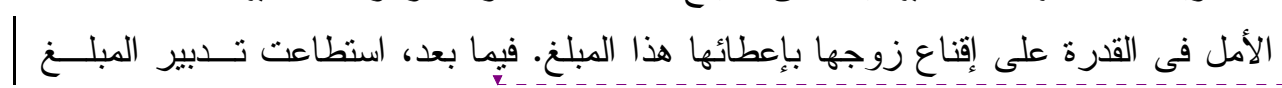

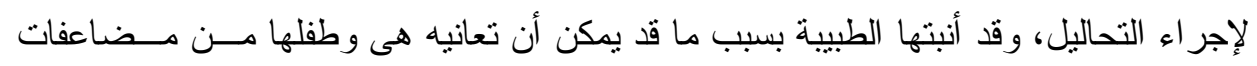
نتيجة للتأخر فى العلاج.

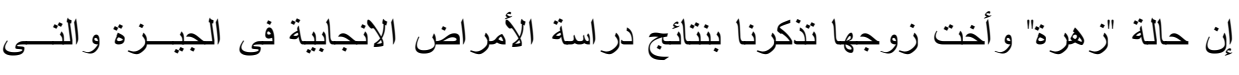

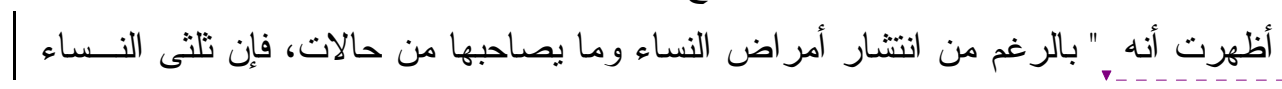


ممن أبلغن عن وجود أعر اض لاديهن لم يلتمسن العناية الطبية رغم وجود مركز صحى فـى

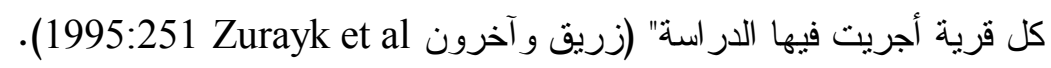

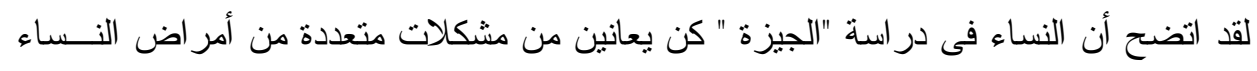

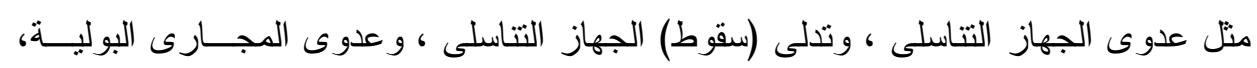

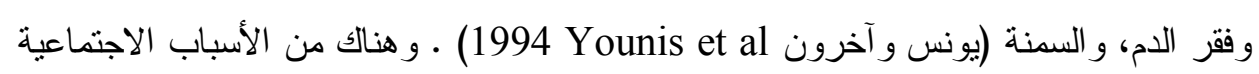

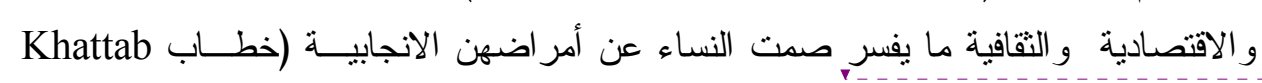

ويظهر من هذه الورقة أن فهم مفهوم النساء عن أجسامهن هو أمر أساسى فى فهــ ســلوك "ز هرة" و "سلوى"، و العديد من النسوة ممن يعانين نفس الحالات فيما يتعلق بصحتهن الإنجابية.

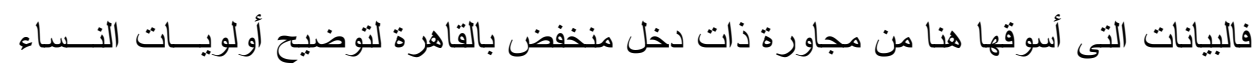

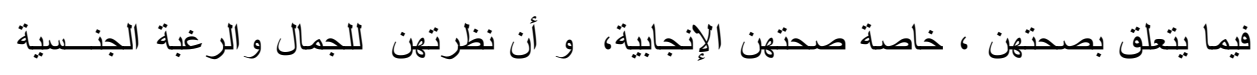

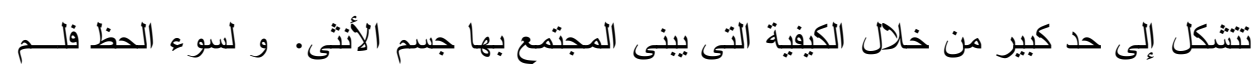

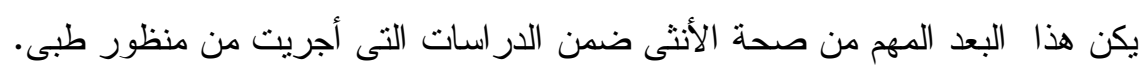

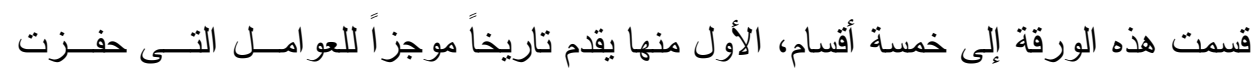

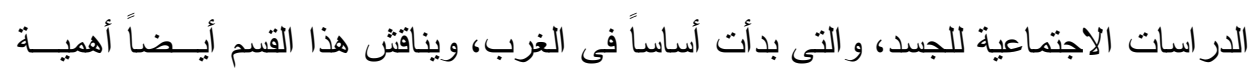

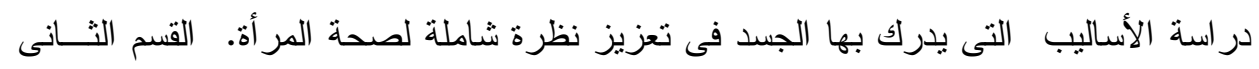

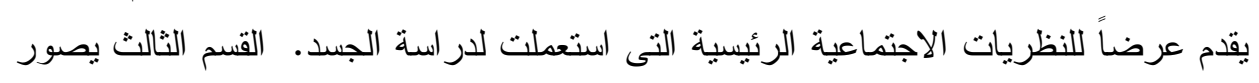

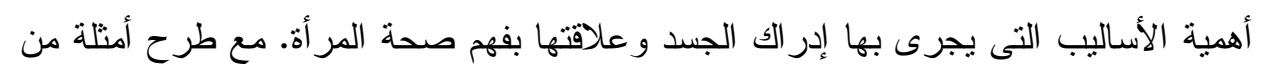

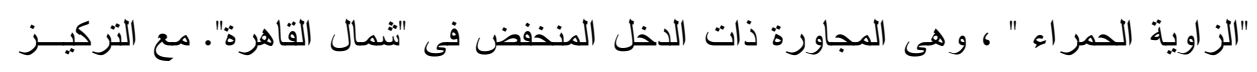

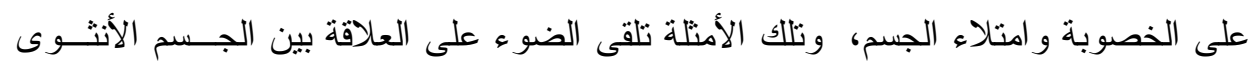

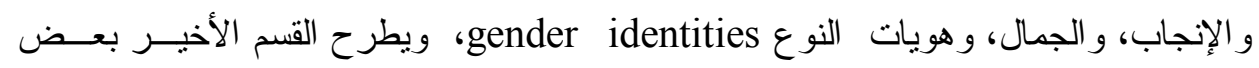

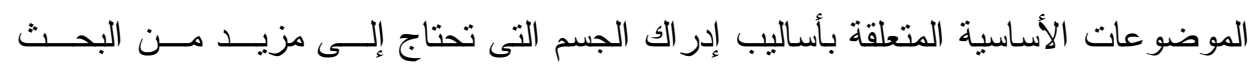
للوصول إلى إدر الك شمولى للصحة الإنجابية للمر أة.

لقد كانت "الز اوية الحمر اء " مقر اً لعائلات هاجرت من الريف أو من منــاطق أخــرى مــن

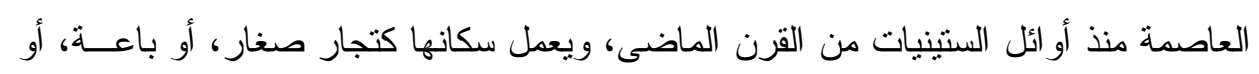

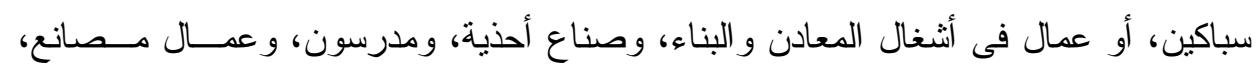

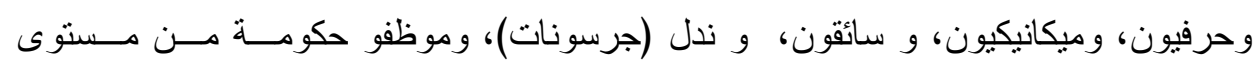

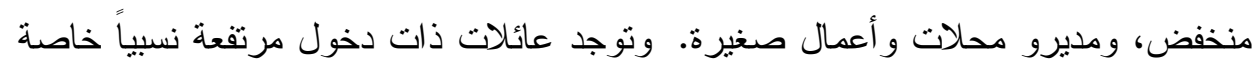




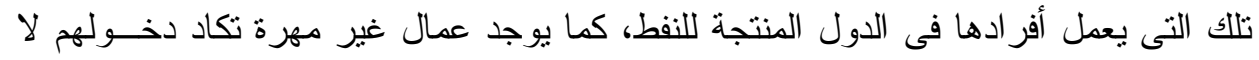
تكفى إعالة أسر هم. ويعمل كثير من الرجال فى أكثر من عمل لبستطيعو ا سد حاجات أسرهم.

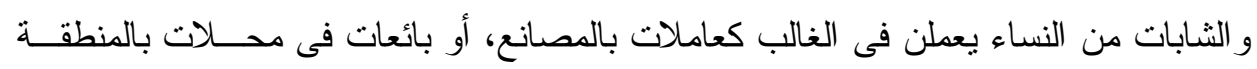

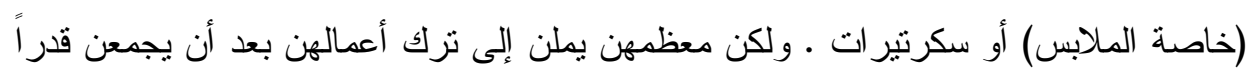

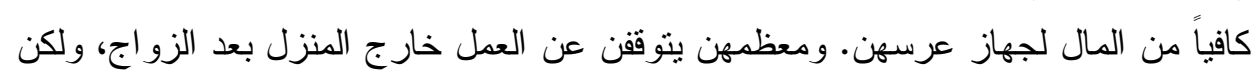
الكثير ات منهن يشاركن فى أنشطة اقتصادية فى محيط الوحدات السكنية.

لماذا ندرس الجسد؟ -II

خلال العقدين الأخيرين أصبح الجسد فى العلوم الاجتماعية فى الغرب مركز اً لنطاق و اسع من

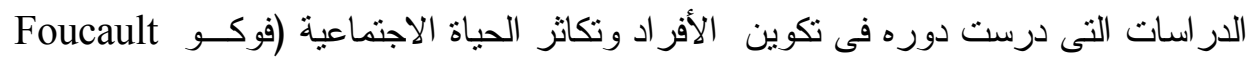
1979 ، 1980، 1990، بورديــــ 1984 Bourdieu

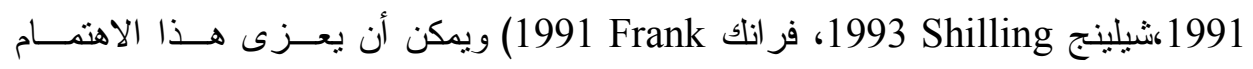
بالجسد إلى تغير ات متعددة، (تيرنــر 1991 Turner، ســينوت 1992 Synnott، مـــارنت فئن 1992 Martin

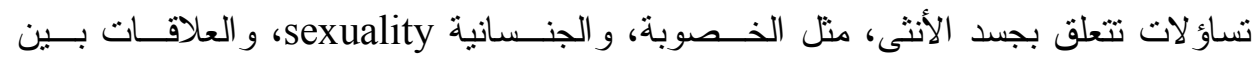

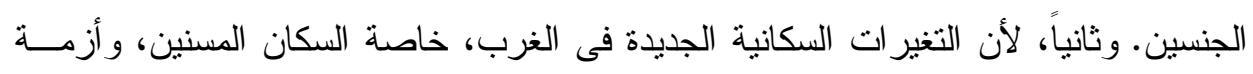
الإيدز ، و التلوث البيئى المتصاعد، قد ولدت مخاوف سياسية تتعلق بالخدمات الصحية، و العلاج

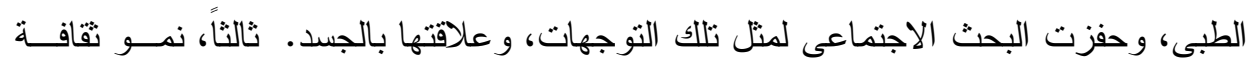

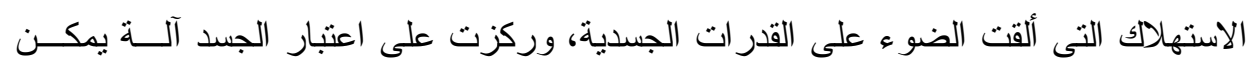

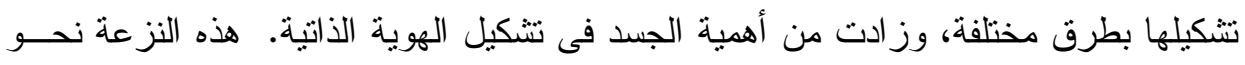

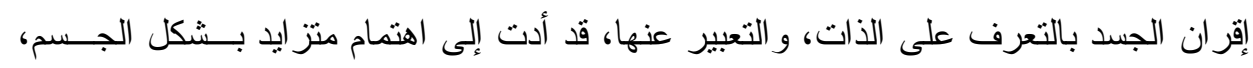

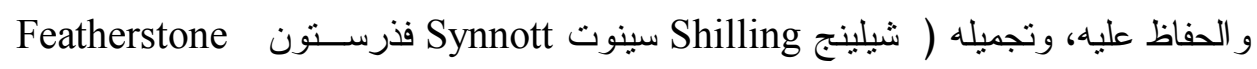

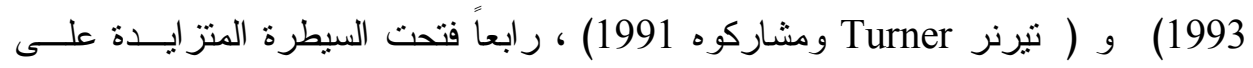

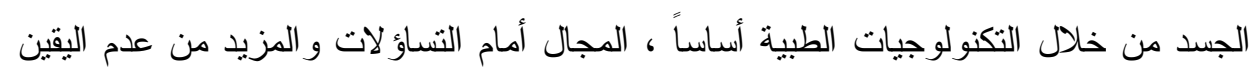

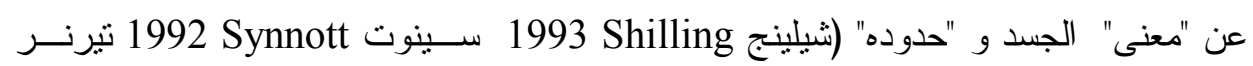
1991 Turner المسائل المتعلقة بالجسد خاصة جسم الأنثى. منل الحق فى الإجهاض، ومنع الحمل، و الثقنيات

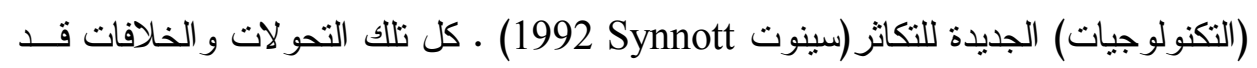
شكلت الكيفية التى وضع بها علماء الاجتماع نظرياتهم عن الجسد وتحليلاتهم له. 
يتتامى الآن الاهتمام فى الثرق الأوسط بكثثر من الأمور المرتبطة بالجسد ـ فــثناً تطـــرح

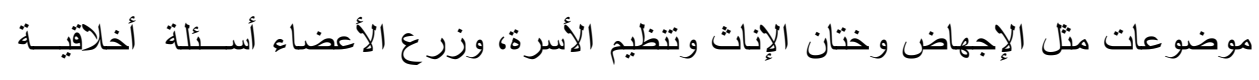

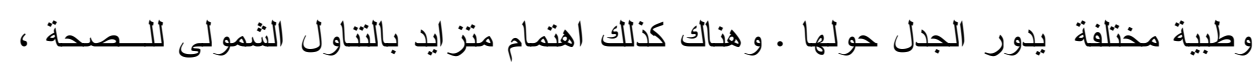

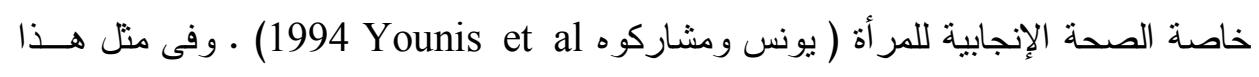

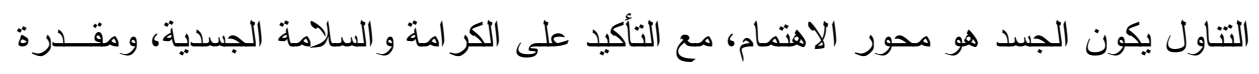

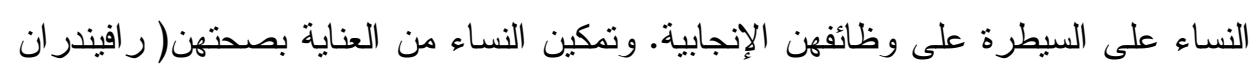
1995 Ravindran 1995

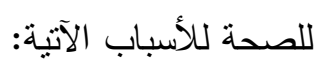

أولًا: إن الجسد هو "وسيط ثقافى Medium of culture " (بوردو 1989 Bordo وموضع

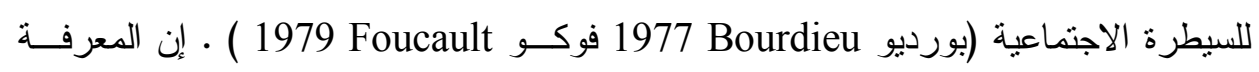

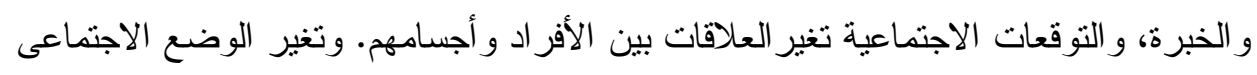

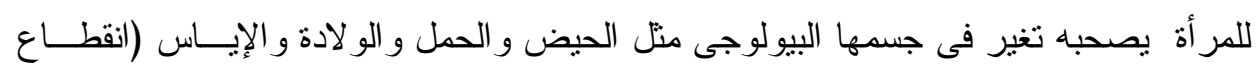
الطمث menopause) • وتلفت تلك الأحداث النظر إلى العلاقات المعقدة بين جسد المــر أة،

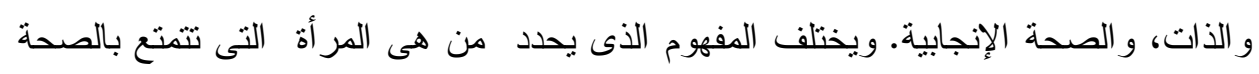

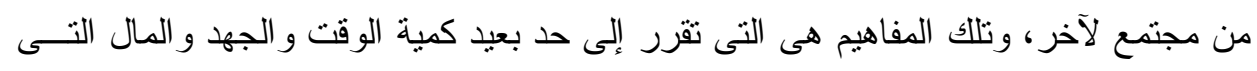

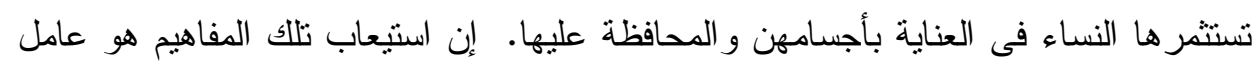

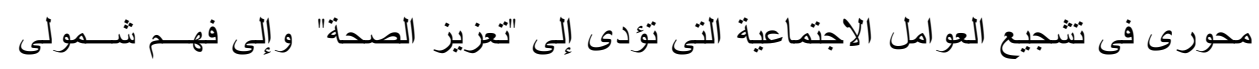

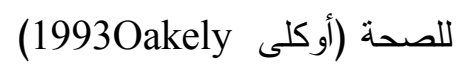

ثانيًا: كانت الانتقادات توجه إلى النظام الطبى الحيوى biomedical system لتركيزه علـى الأعى

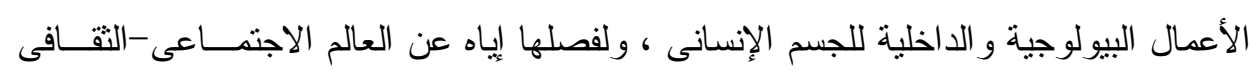

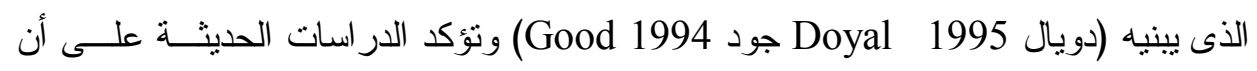

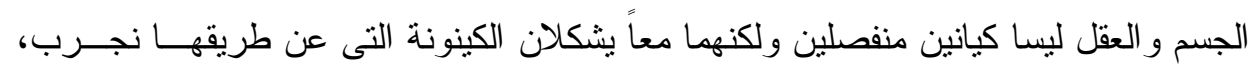

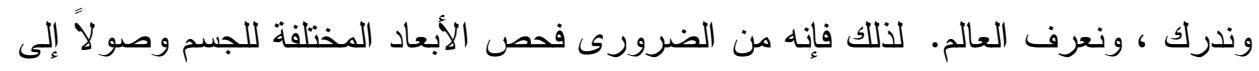
فهم أفضل للصحة و العافية.

ثالثًا: يقوم الجسم بعمل الوسيط فى التقاعلات بين العوامل الاجتماعية خاصنة اللقــاءات بــين

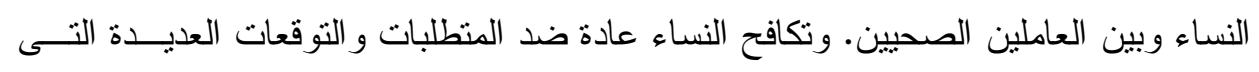


تشكل أجسادهن. فمن ناحية يكون اعتبار الجسم ر أسمال ثــين هــو محــور إدر الك النـساء

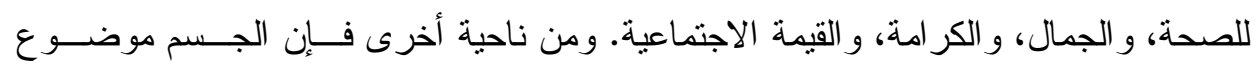

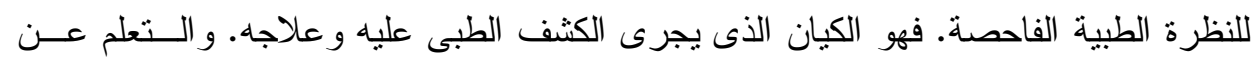

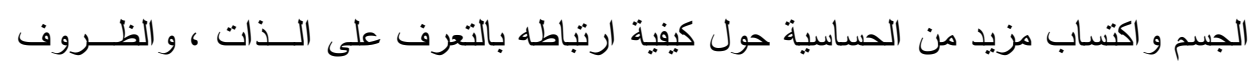

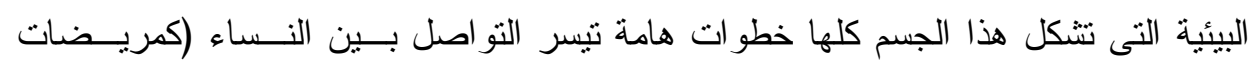

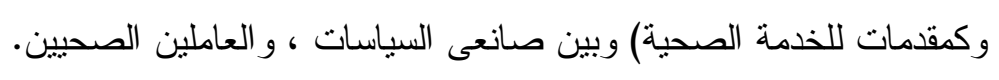

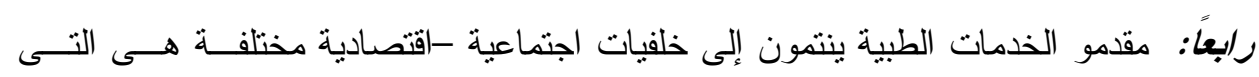

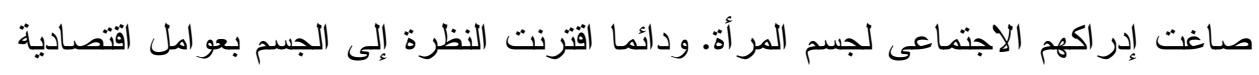

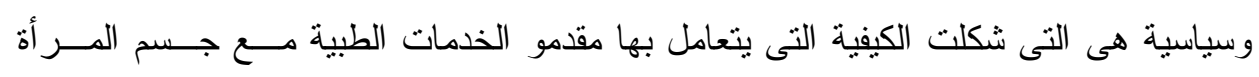

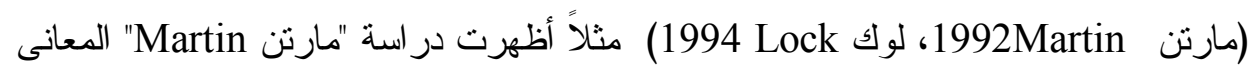

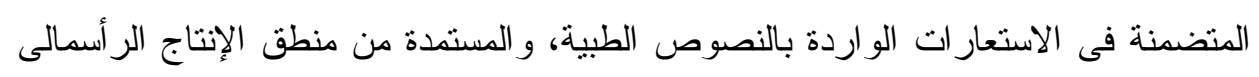

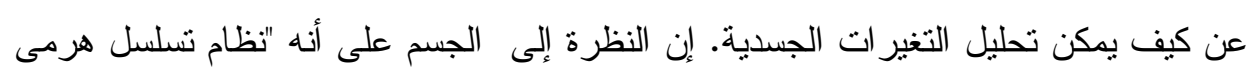

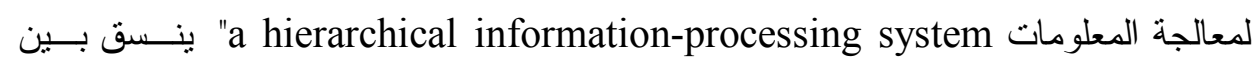

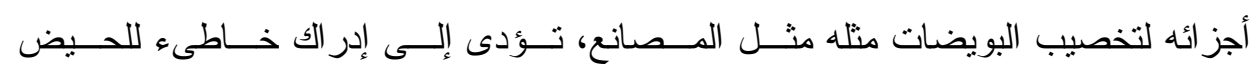

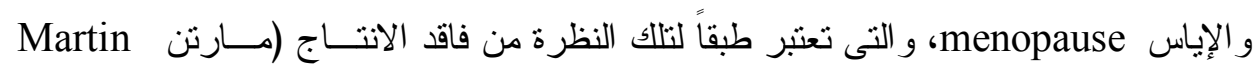

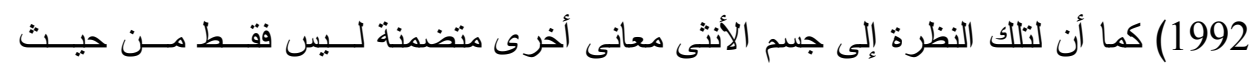

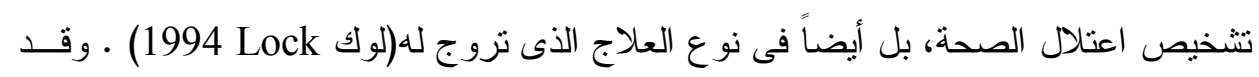

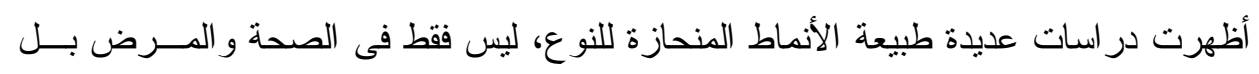

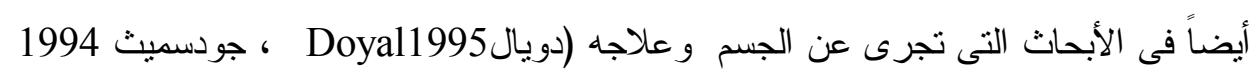

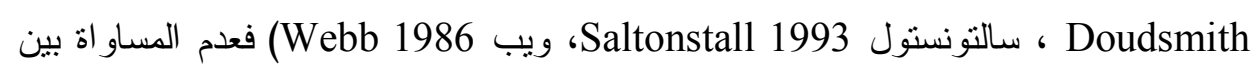

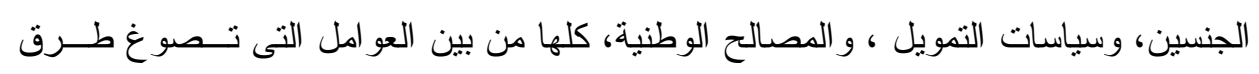

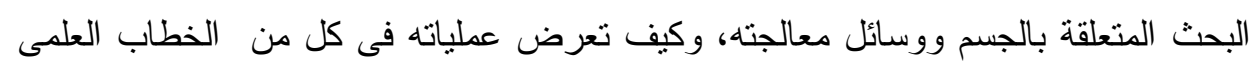

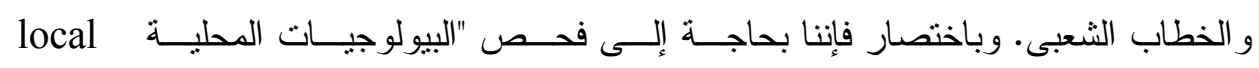
biologies

خامساً: إن در اسة معارف النساء عن أجسامهن لا تساعد فقط على الكثف عن فرضــياتهن

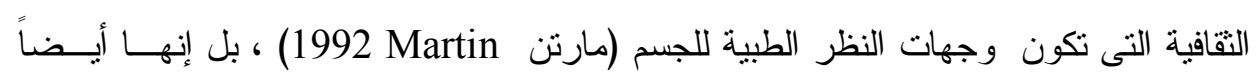

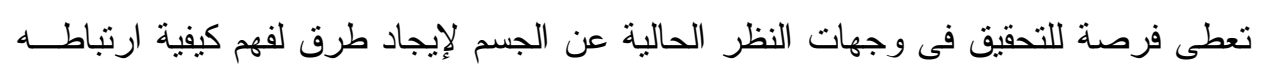


بالصحة و العافية. وبدلاً من طرح نموذج "جسد عام Universal body" يتم تطبيبه بــنفس

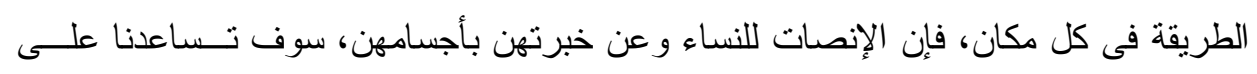

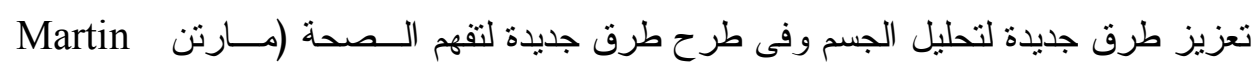

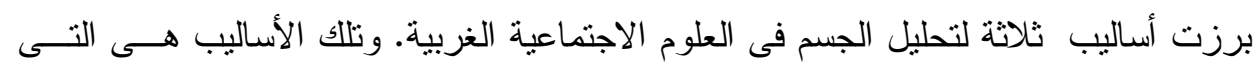

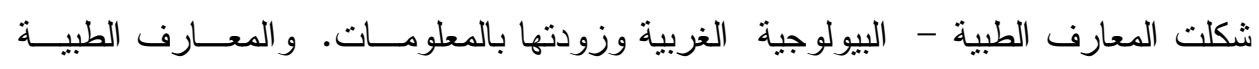
البيولوجية الغربية هى الى تشكل إلى حد كبير الخطاب الطبى و الخدمات الطبية فى منطقتئـا.

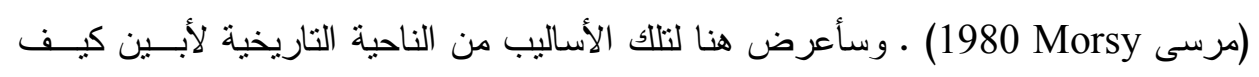

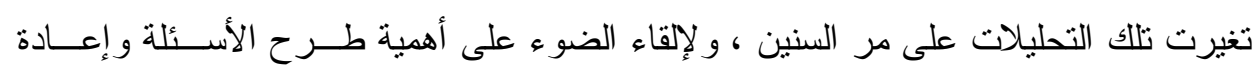

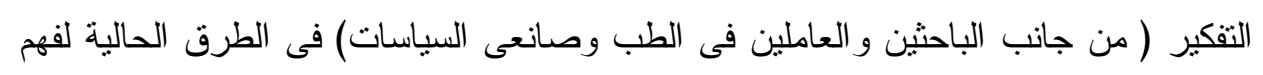

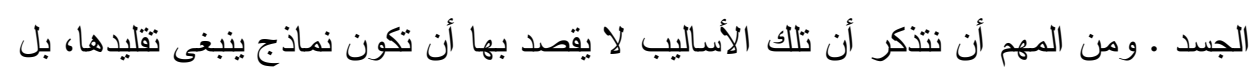

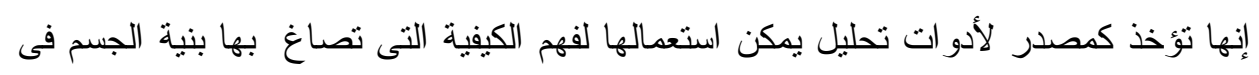

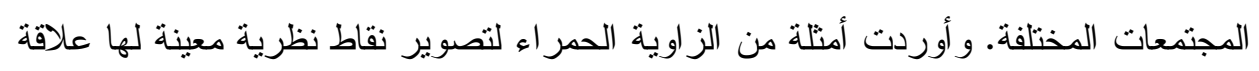

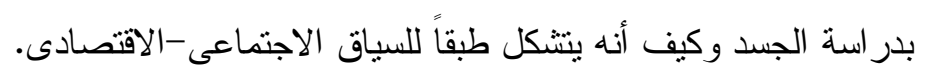

ظهر الأسلوب الأول من الأساليب الثلاثة الكبرى لدراسة الجسد فى القــرن الثـامن عـشر،

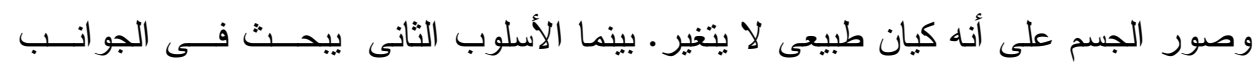

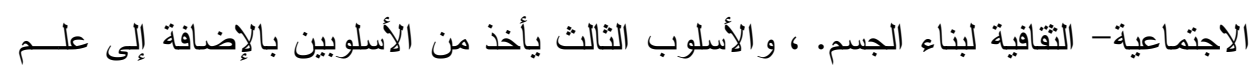

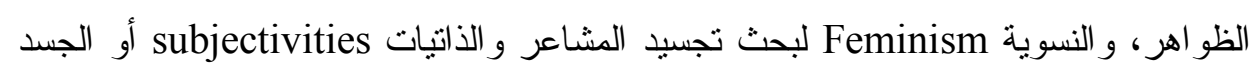

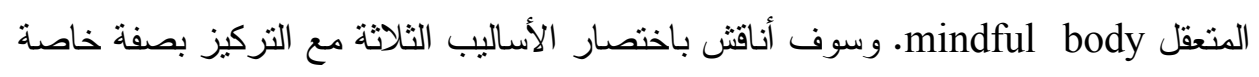
على كيفية تقهمها لجسم الأنثى.

أ- الجسد الطبيعى The Natural Body من المفهوم عموماً أنه حتى نهاية القرن السابع عشر كانت العلوم الاجنماعية الغربية تتظــر

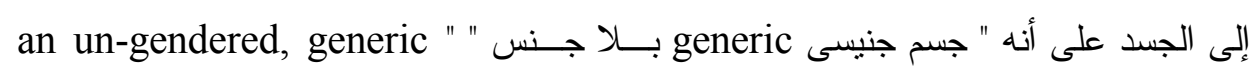

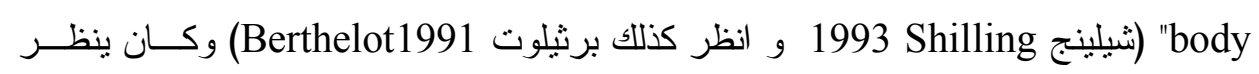

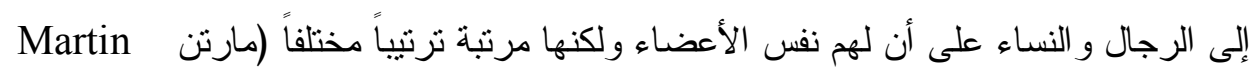


1992) • وبرغم حقيقة أن عدم المساو اة بين الذكور و الإناث كانت قائمة، إلا أن دونية المرأة لم تكن ينظر إليها باعتبارها موروثة بصفة خاصة وثنابتة داخل أجسامهن" (شيلينج 1993 Shilling

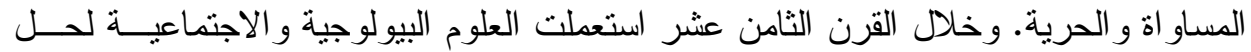

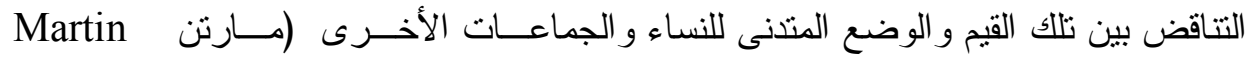

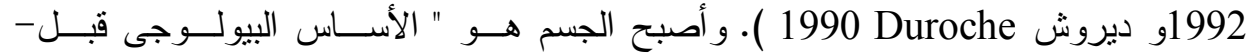
Shilling الاجتماعى pre-social الذى بنيت عليه البنى الفوقية من الذات و المجتمع" (ثيلينج

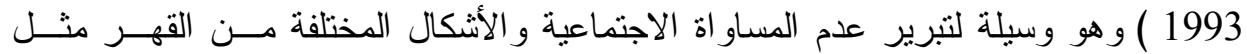

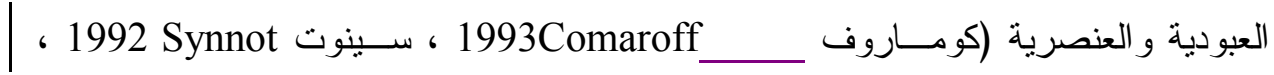
مارتن Martin1992) • وقد بدأ استخدام الصفات الجسدية مثل اللون وحجم الجمجمة، لتفسير

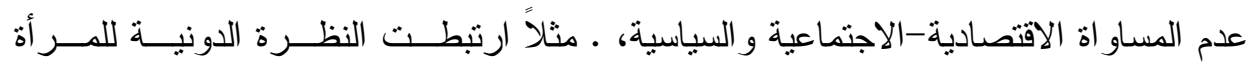

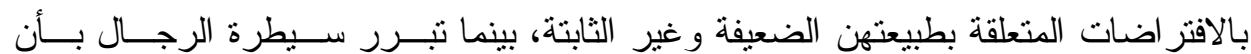

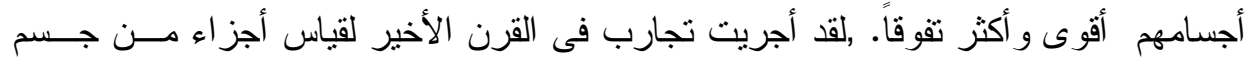

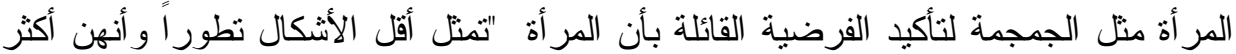

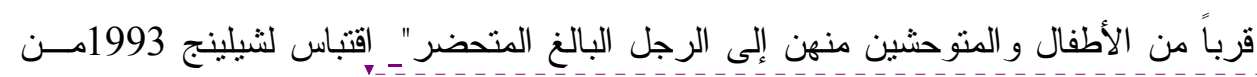

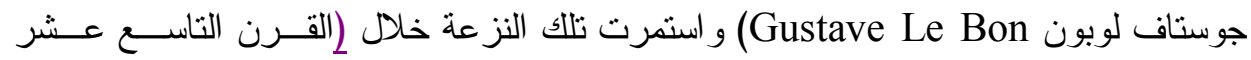
وتركزت التفسير ات الطبية لحالة المرأة حول افتز اض أن الذى يقود المــر أة هـــو وظائفهــا

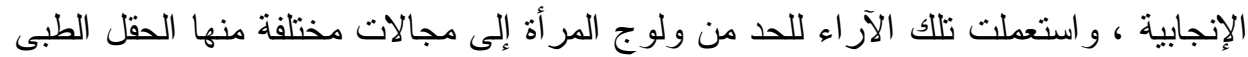

ويقترن شيو ع ذلك الأسلوب بحقيقة أنه يجعل لأساس التقرقة الاجتماعية مكانــاً فــى الجـسم

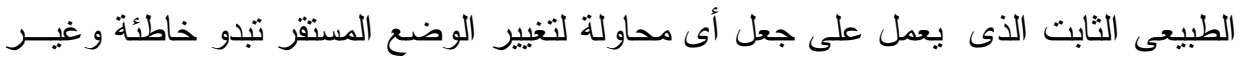

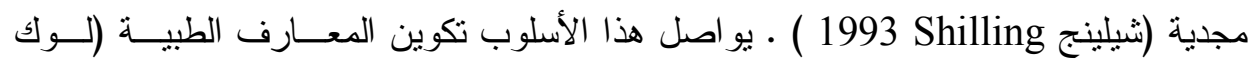
1993 Lock

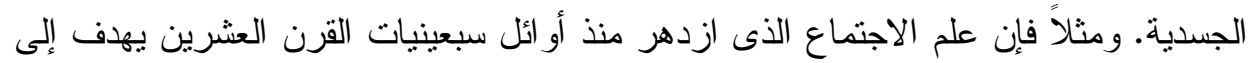

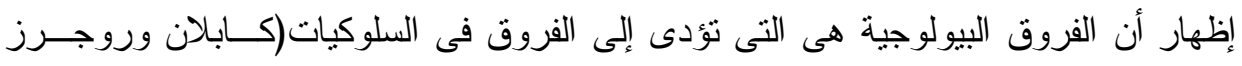
1990 Caplan and Rogers

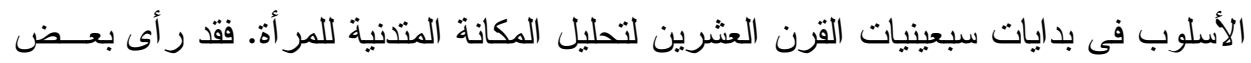

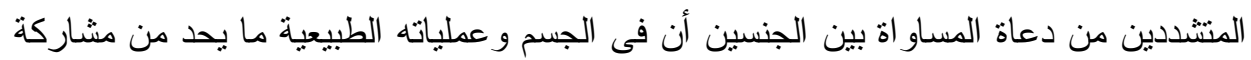

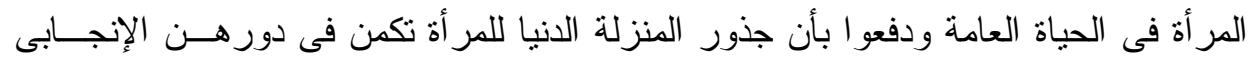


(انظر جروسز 1994 Grosz، كابلان وروجـرز 1990 Caplan and Rogers، كيـنج 1989 King

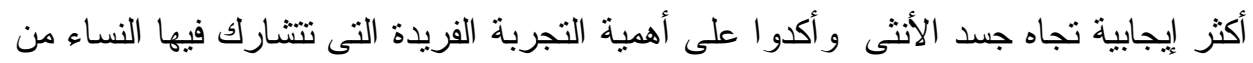

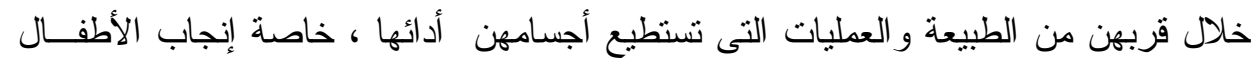
(انظر جروسز 1994 Grosz، كابلان وروجـرز 1990 Caplan and Rogers شـــيلينج (1993 Shilling

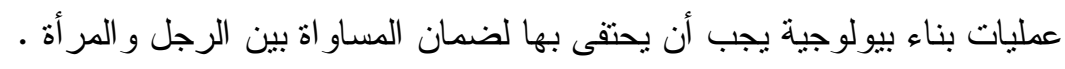

إن الإسهام الرئيسى لهذا الأسلوب هو تأكيده على أن الجسد هو أساس العلاقات الاجتماعيــة.

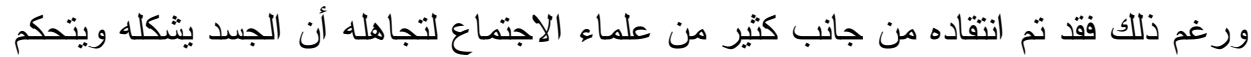
Shilling فيه ماهو موجود من علاقات القوة و العمليات الاجتماعية و المعانى الثقافية.(ثيلينج

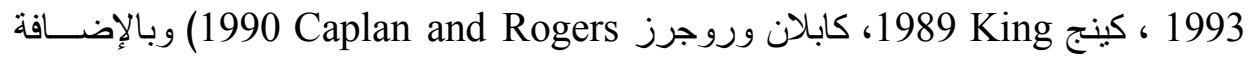
إلى ذلك فإن هذا الأسلوب يعمل ضمن ثنائيات جامدة مثل أبيض/أسود، ذكر/أنثى ليبرر عدم

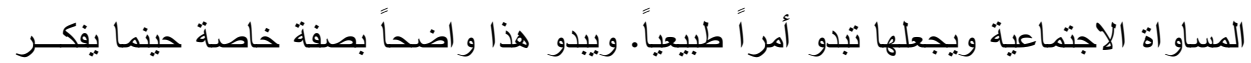

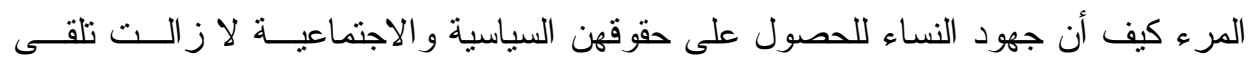
مو اجهة نستتد إلى نظريات الجسم التى تؤكد أن البيولوجيا النسائية من مرتبة أدنى (كـابلان

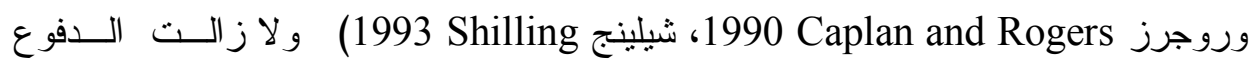
البيولوجية مثل افتر اض أن سلوكيات المر أة تحكمها الهورمونات خاصة في متلازمة ما قبــلـل

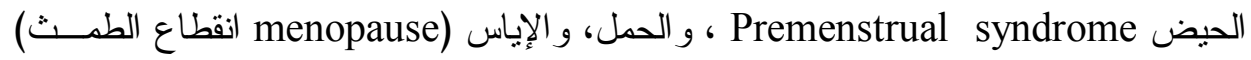

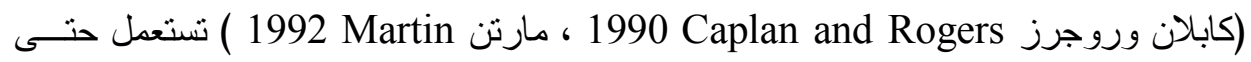
الآن للحد من مشاركة المر أة فى الحياة العامة.

باء - البناء الاجتماعى للجسم The Social Construction of the Body

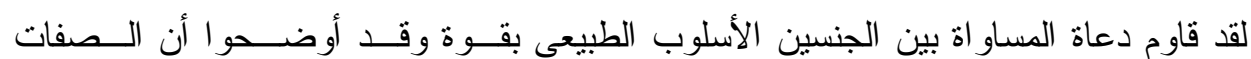

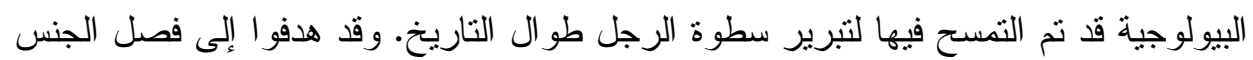

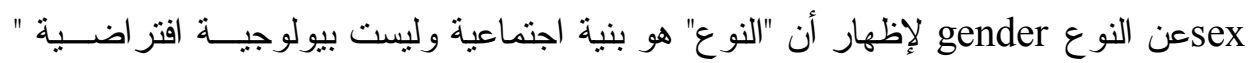

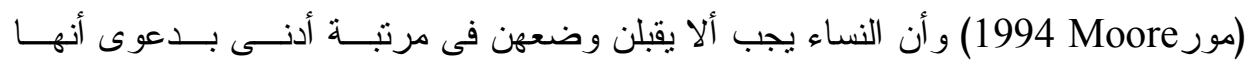

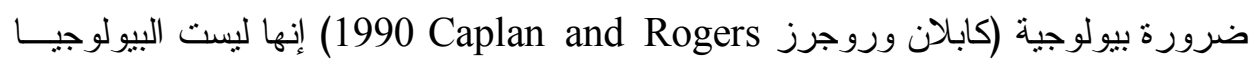
بل إنها الطرق التى بها " يدبر النظام الاجتماعى البيولوجيا ويعطى لها معنى يكرس قهـر

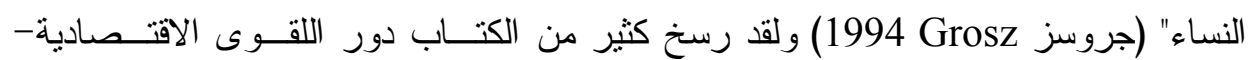


الاجتماعية و الثقافية، و السياسية فى نتكيل الجسم (مارتن Synnott 1992 Martin سينوت 1993 فوكو 1980 Foucault، 1985، جوفيمان 1959 Goffman إن تلك الدراسـات

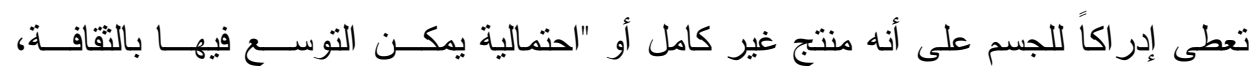

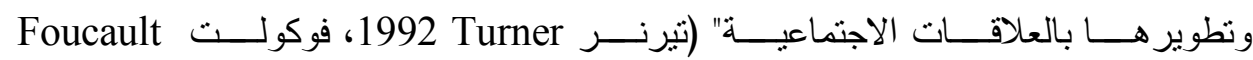

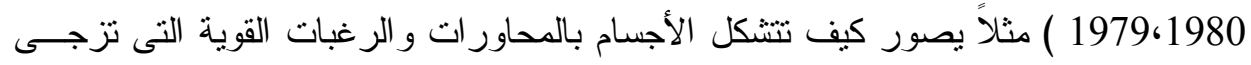
إلى الناس على أنها على أنها "حقائق" تتظم وتنبى الكيفية التى يتم بها فهم وممارسة الأجسام. تصدر مثل ثلك الخطابات عن وكلاء ومنظمات متعددة، منل الدولة، و الثخــصيات الدينيــة، العاملون فى الطب، و المدارس، و الرجال، وعجائز النساء.

و "أم عاطف" هى أحد الأمنلة الدالة على كيف يشكل النظام الصحى خبرة المر أة بجسمها، وأم

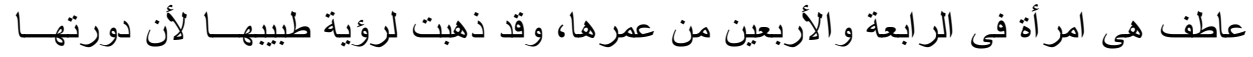

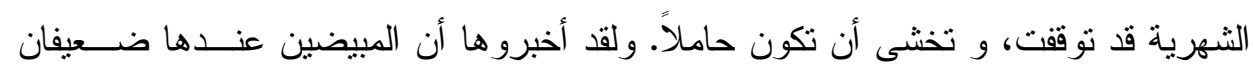

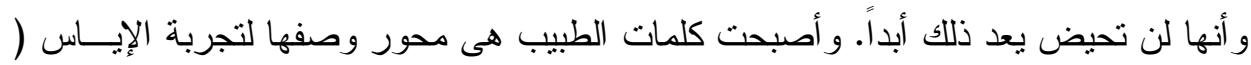
انقطاع الطمث)عندها. وقد تم تنبيهها إلى الفور ات الساخنة hot flushes (هبات ساخنه) التى

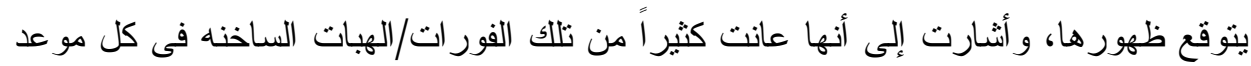
للاورة منذ ذلك الوقت وحتى الآن.

وفى القصص المتداولة فى الزاوية الحمر اء مثال آخر لإيضـاح كيف يشكل المجتمع الطريقــة

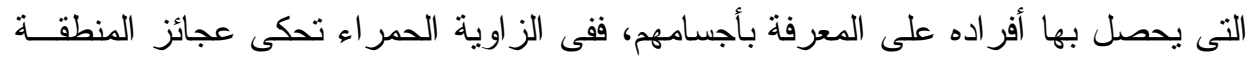

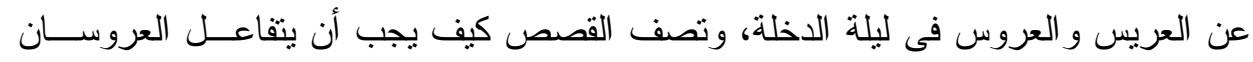

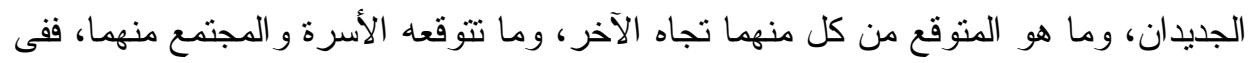

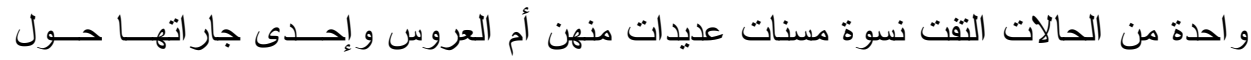

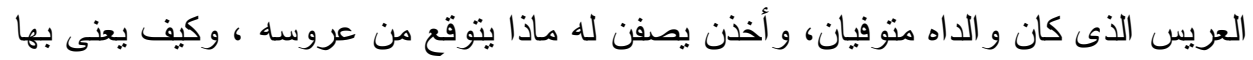

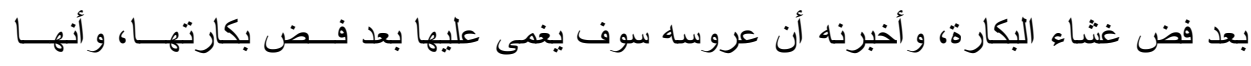

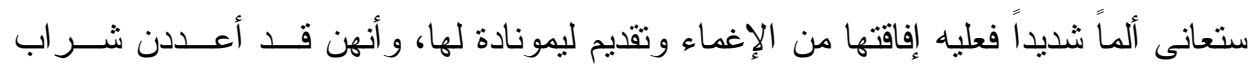

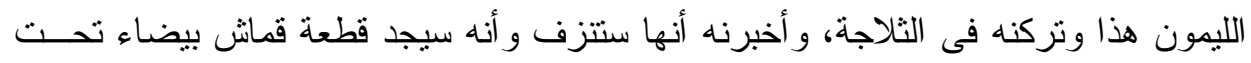

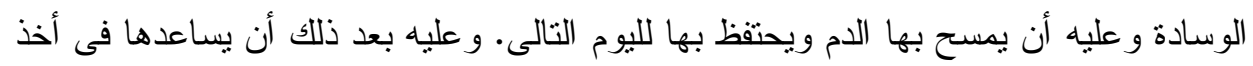


كانت أوصاف كل عروس فى الز اوية الحمر اء لليلة زفافها متطابقة مع القصص التى ترويها

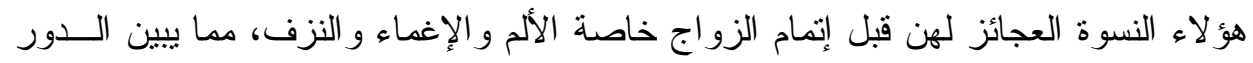
القوى الذى تلعبه تللك القصص فى خبرة العر ائس بأجسادهن.

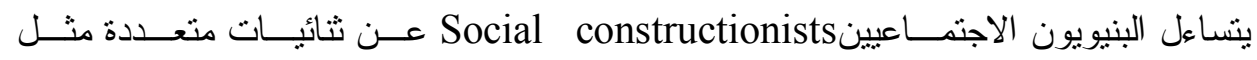

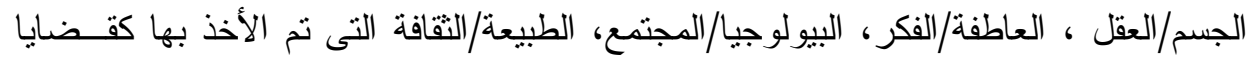

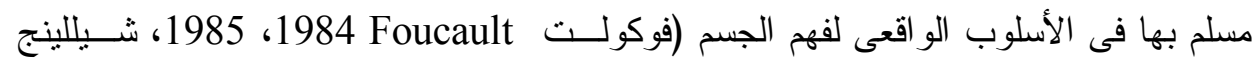
1993 Shilling طبيعية، وسابق منحها، و أبدية" قد ثبت أنها بنى (جمع بنية) ثقافية (مور (1994Moore) رغم

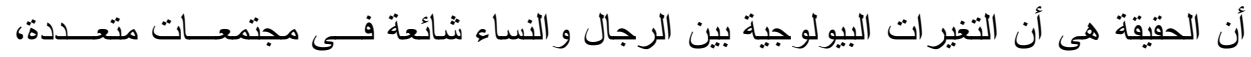
فمعنى مثل تلك الفروق يختلف لدرجة كبيرة و أن تلك الفروق مرتبطة ارنباطاً شديداً بالسياق.

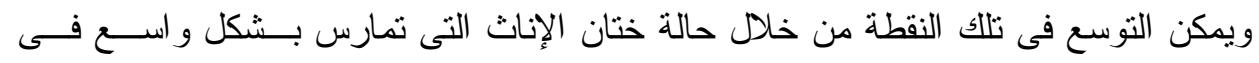

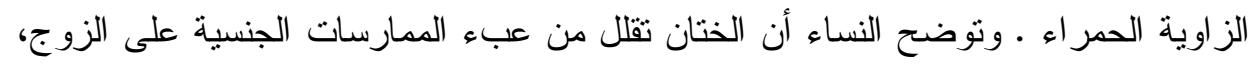
وتجمل وتطهر جسم المر أة، التى لا يجب أن تمتهن نفسها بطلب المعاثرة الجنسية.

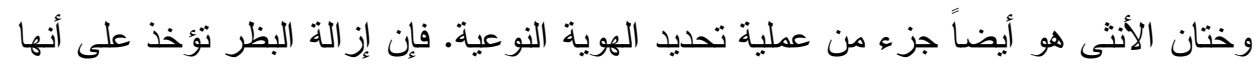
عملية أساسية لدمغ هوية (الأنثى) على جسمها. ويز عمون أن البظر لو لو لم يتم بتره فإنه سينمو

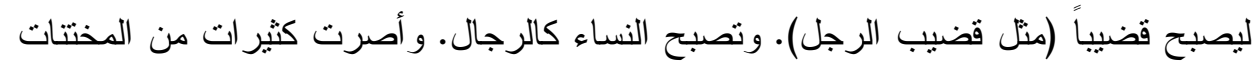

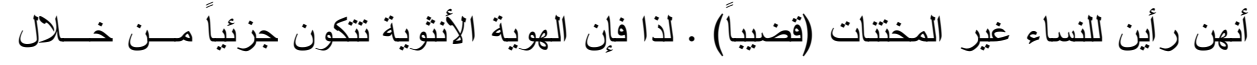

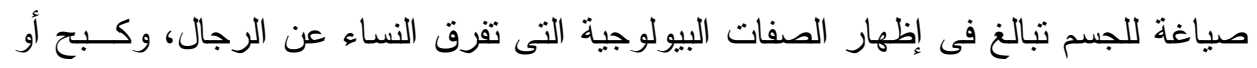
إز الة الصفات الطبيعية التى يعتقد أنها نتابه جسم الرجل. لذللك فإنها ليست الكينونة البيولوجية

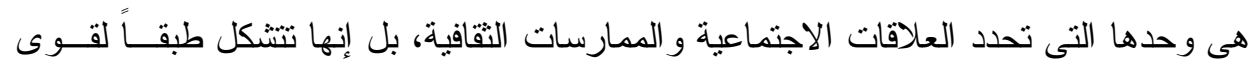

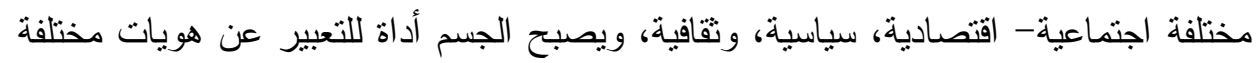
فردية وجماعية، و عن تثتيت تلك الهويات.

The Mindful Body الجسد المتعقل كان الانتقاد عادة يوجه إلى البنيويين الاجتماعيين Social constructionists لذهابهم إلـى

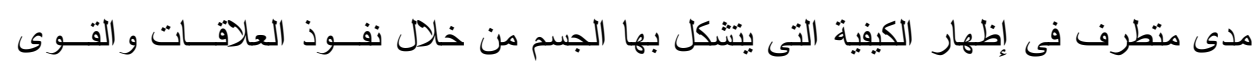
الاقتصادية-الاجتماعية، بينما لا يعيرون أهمية أو يعيرون أهية ضئيلة فقط للجو انب المادية

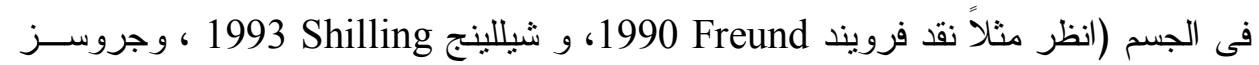


1994 Grosz

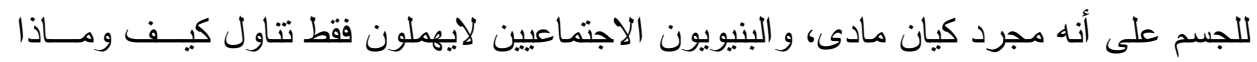

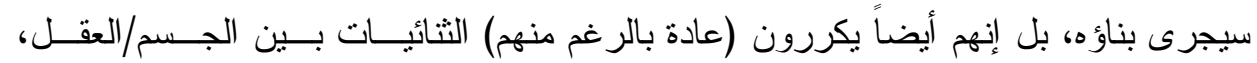

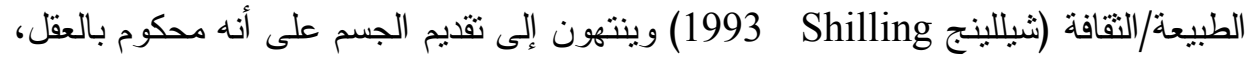

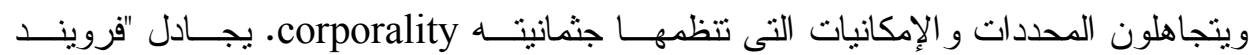

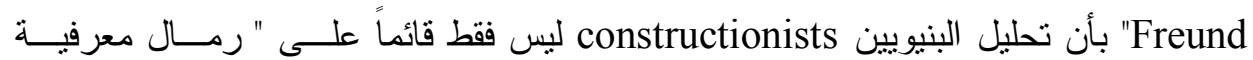
متحركة epistemological quicksand" بل إن هذا التحليل بما له من نزعات نسبية يحول دون استعمال هذا الأسلوب فى صياغة " سياسة اجتماعية أو أى رؤية عن كيف تكون الصحة

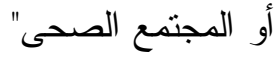

تحاول الدر اسات الأكثر حداثة أن تتجنب تلك الهفوات فى تحليل الجسم وأن تنبى حول الإسهام الإيجابى للبنيوية الاجتماعية و الذى يظهر كيف أن الطبقة و النوع و الدين و العـــرق، و الإثتيــة

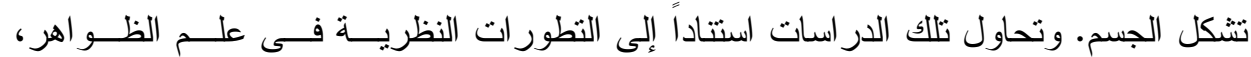
و النسوية feminism أن تتجاوز ثنائية الجسم/العقل لإظهار كيف أن الجسم هو " الأرضـــية

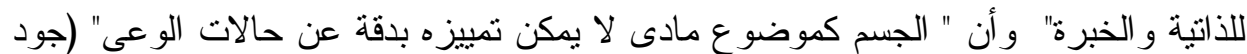
(1994Good

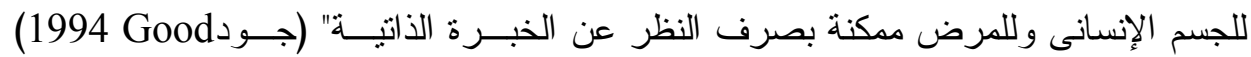

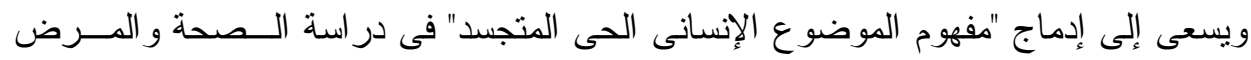
(فرويند 1992Freund ، دويل 1995 Doyal ، جروسز 1994 Grosz ) إنهم يحساولون تقديم منظور أكثر شمولاً يسبب التقاعل المعقد بين البيولوجيا، والأنشطة العقلية والاجتماعية.

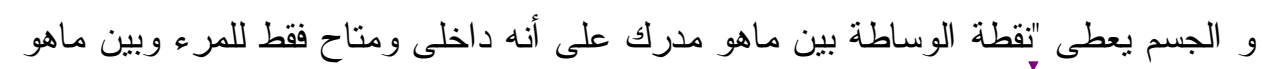

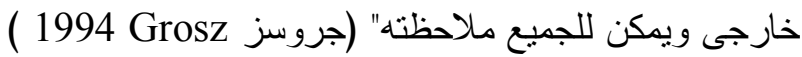
إننا نستكثف العالم بأجسامنا: العالم نتيجة لمرض ونطئ خطير أصبح غير كامل، محطم، أو متبدل

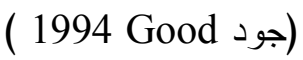
التركيز على الجسم المتعقل أو العقل المتجسد هو إذن أمر أساسى لإدر الك " التتاغم و الوحدة

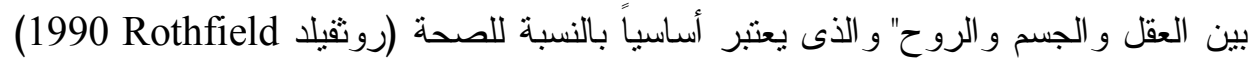

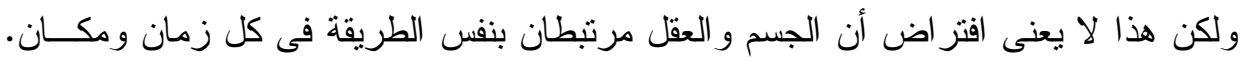

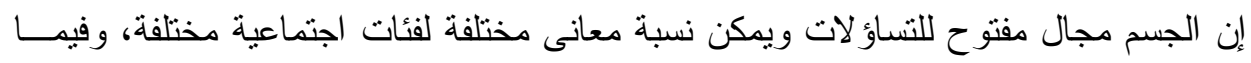

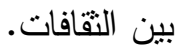


الرجال و النساء، الثباب و الثيوخ، و الناس من مختلف الثقافات يعرفون وينشئون رو ابط بـين

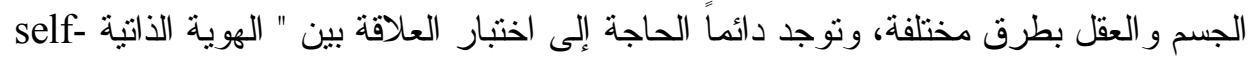

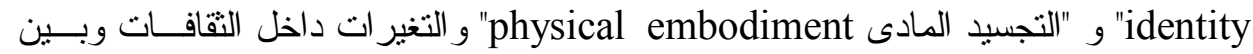
بعضها البعض. (مور 1994 Moore) إن مناقثة تلك الأساليب الثناثة تلقى الضوء على الحاجة إلى فحص ومعرفة التجسد وكيـف لفـ يُّنكل وكيف يتتكل من خلال السياق الاجتماعى_التقافى. وفى القسم التالى سأعرض بيانــات إثثنية من "الز اوية الحمر اء " لإيضـاح بعض جو انب التجسد، وكيف تزتبط بالهويــة و العافيــة. وستركز المناقثات على القيم الاجتماعية المرتبطة بوظائف معينة للجسم وكيف يتم تـشكيلها

إن حالة "زهرة" و أخت زوجها توضح كيف أن النساء يناقـشن احتياجـاتهن الـصحية مــع

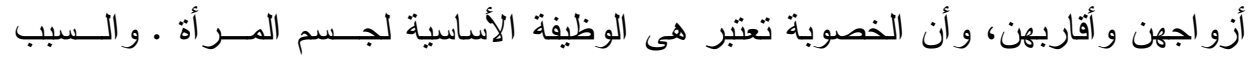

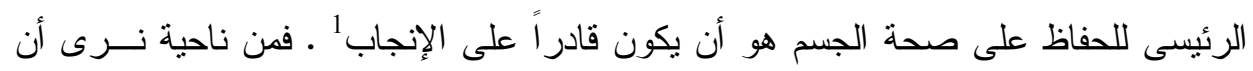

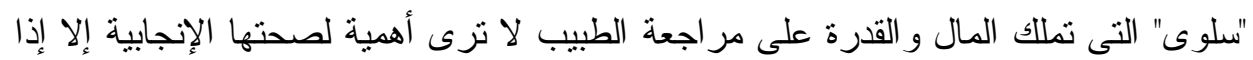

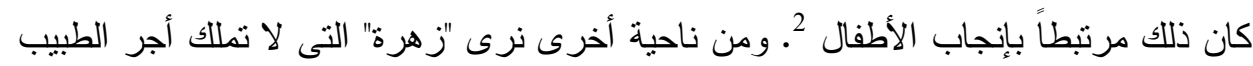

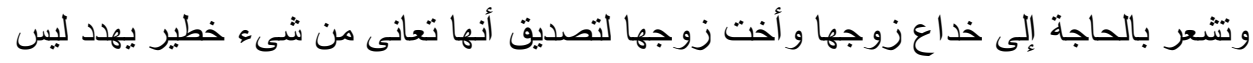

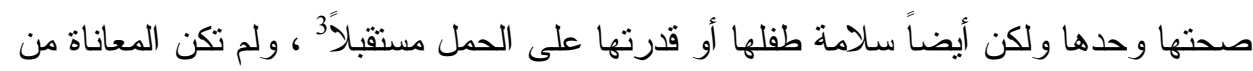

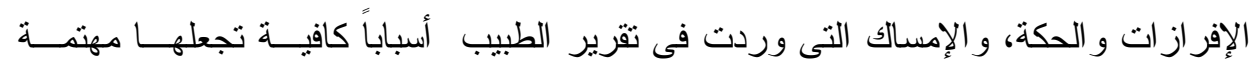

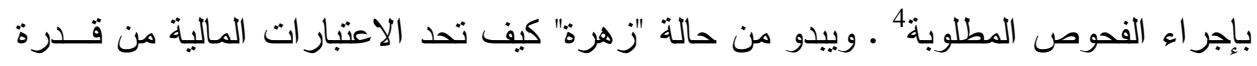

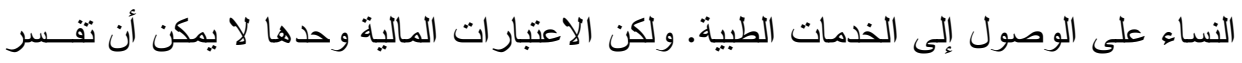

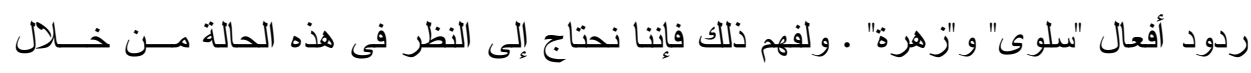

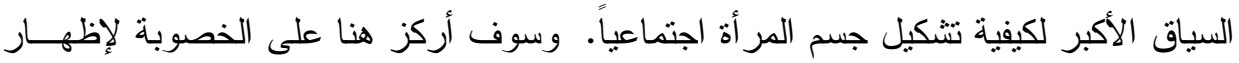

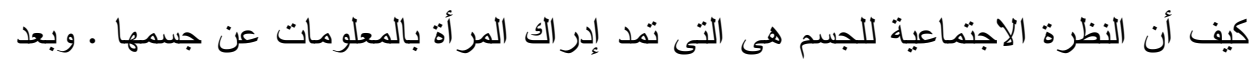

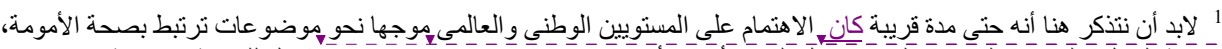

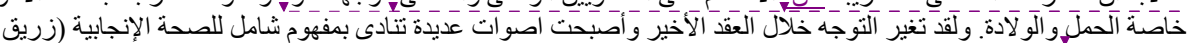
(1991 Miles 1994 و $19 \overline{\text { Zurayk }}$

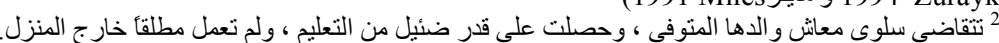

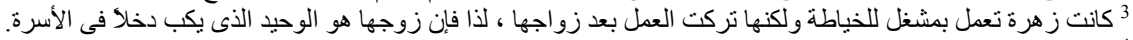

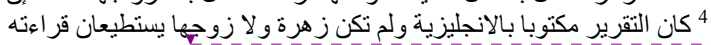

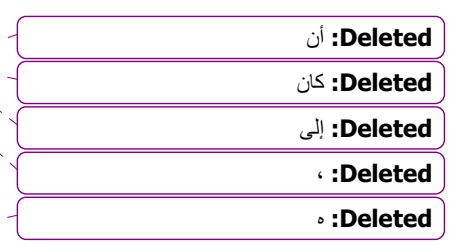


ذللك سوف أتحدث عن امتلاء الجسم، لتوضيح كيف نتكون اجتماعياً القيمة التى ترتبط بأثنكال معينة للجسم و التى ترنبط ارتباطاً وثثقاً بمختلف الممارسات اليومية.

أ- الخصوبة والجسد الذى اكتسب صفة النوع Gendered Body

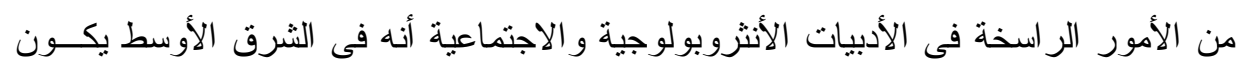

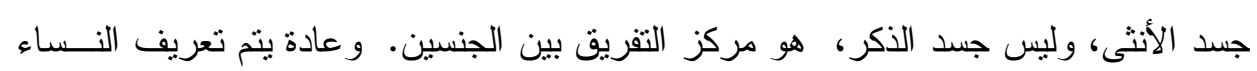

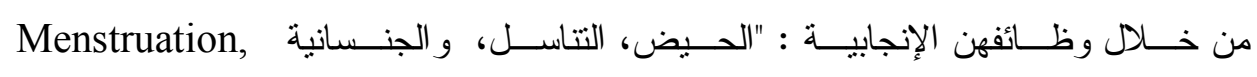
procreation, and sexuality كيف تعتبر جنسانية المر أة اجتماعياً خطر اً يهدد الاستثرار الاجتماعى و نظرت فى محاولات

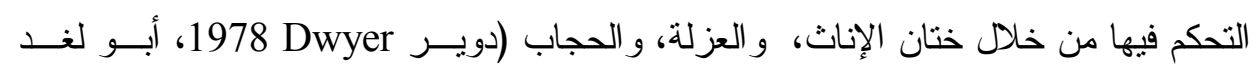
1986 Abu-Lughod جنسانية المر أة مرتبطة إلى حد كبير بشرف العائلة ونوضع القبود على جسم المر أة للمحافظة

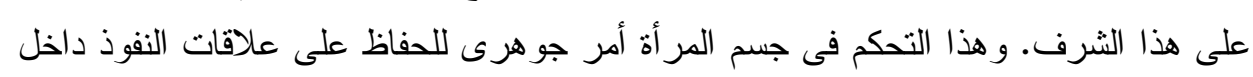

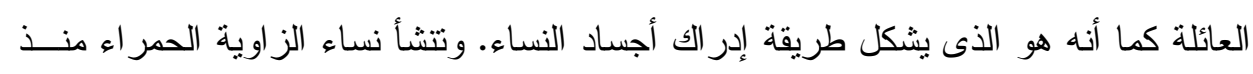

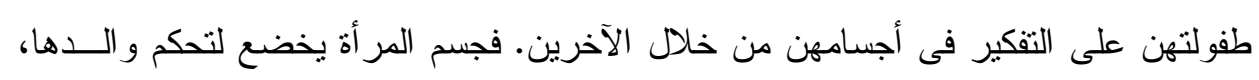

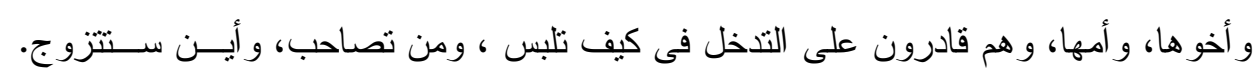

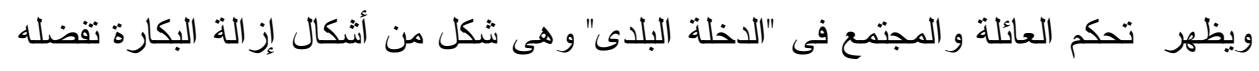

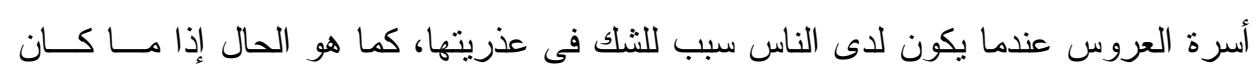

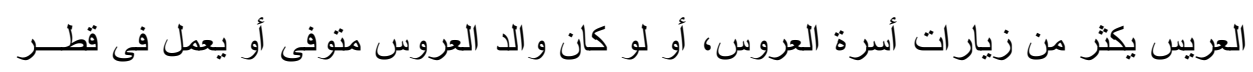

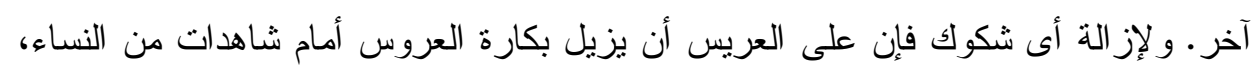

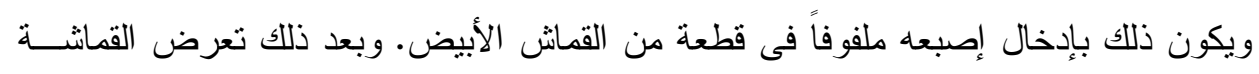

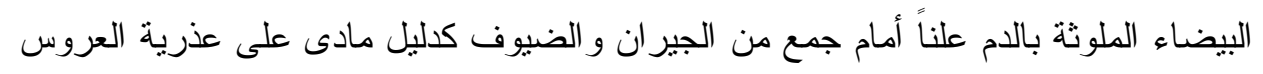
وشرف العائلة.

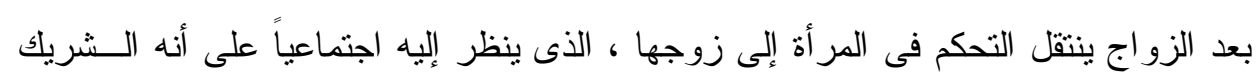

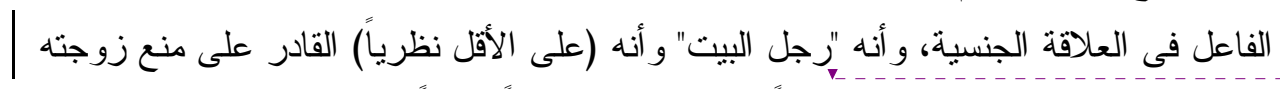

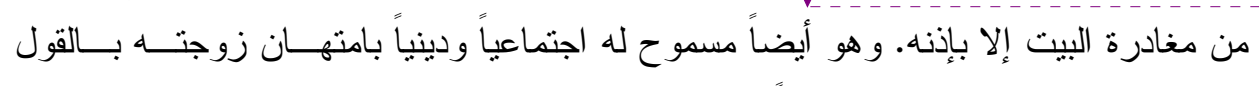

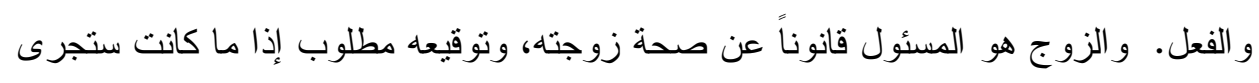

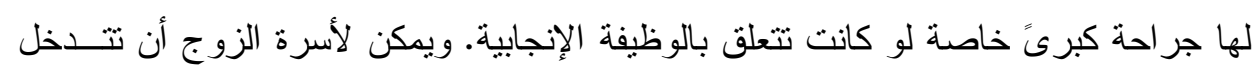

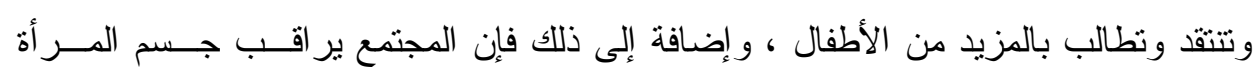


لإجبار ها على التقبد بقيم العفة و ألا يبدو جسمها إلا فى ثياب محتشمة، و الخجل هو على سبيل

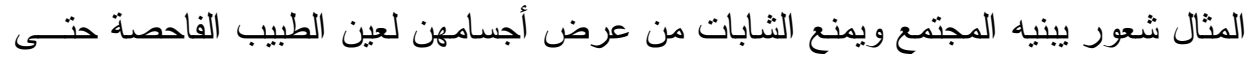

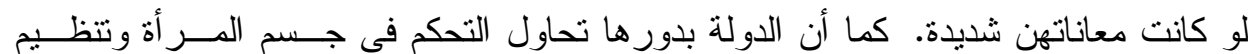
استعماله من خلال تتظيم الأسرة، و التشريعات ، و المدارس، و المؤسسات الطبية.

وحتى الوظيفة الإنجابية للمر أة قد استولى عليها الرجال. فبينما تكون المر أة هى أول من يوجه

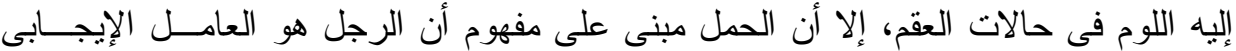
الوحيد فى تكوين الجنين فهو الذى يزرع (البذرة)، فى (الوعاء)، ولهذا فهو (عصب) الحمل.

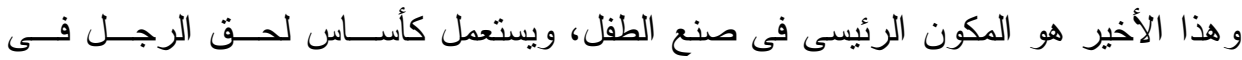

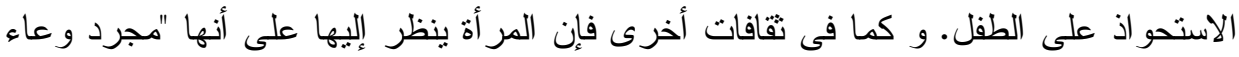

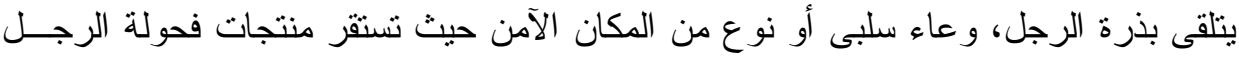
لفترة ما ثم تتشر بعد ذلك قدر اتها الإنسانية" (كريس 1993Krais) لذلك فمن العسير علـى تلى نساء الزاوية الحمر اء أن يشعرن بأنهن يتحكمن فى أجسامهن وفى كيفية استعمال و إظهار هذه

أيضاً فإن الجسم هو "رأسمال" معظم النساء المتعلمات تعليماً بسيطاً واللاتى لم يلقين التشجيع على العمل، وطبقاً لبورديو (Bourdieu 1984) فإن الجسم هو "رأسمال طبيعـى" يمكـن فئن تحويله إلى رأسمال اقتصادى (أى مادى) ، و اجتماعى (علاقات و ارتباطات) وتثقافى (تعلـيميم

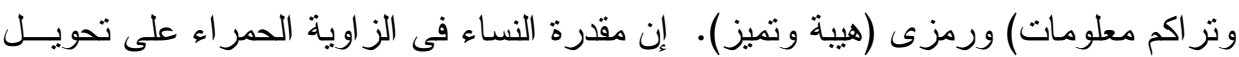

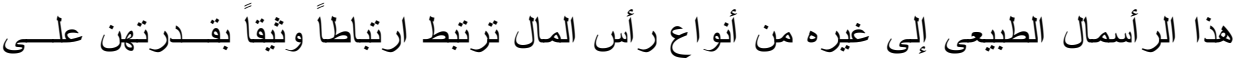

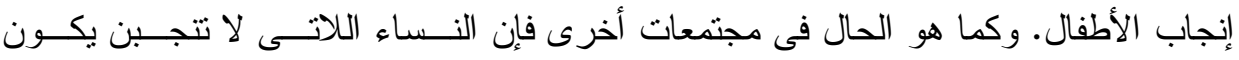

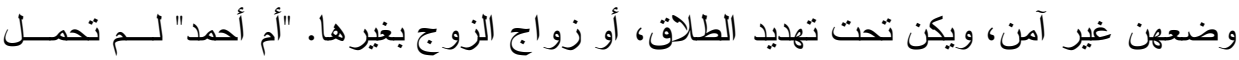

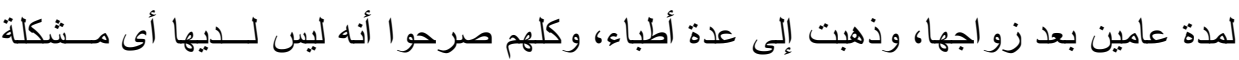

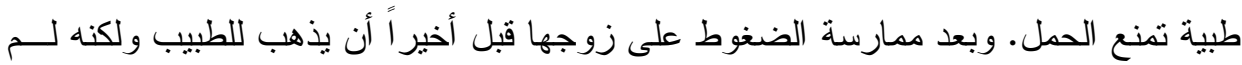

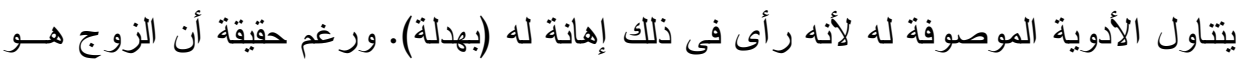

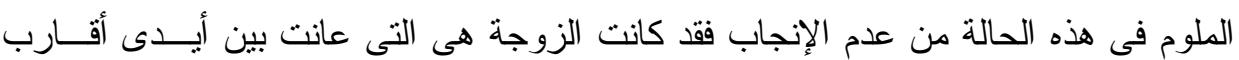

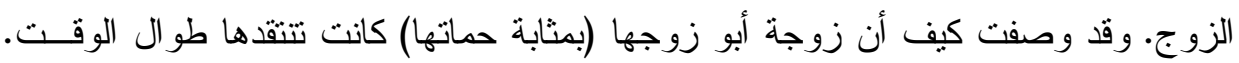
وكانت توصف بأنها " الثجرة التى لا تثر ويجب قطعها" و " الجاموسة التى لا تحمل حلال زوله

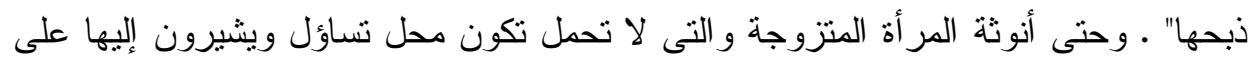
أنها "دكر" (إنهورن Inhorn 19994 ) إذن فالأنوثة و الكيان النسوى لا يرنبطان فقط بحيازة 
أعضاء التأنيث، ولكن أهم من ذلك بإنجاب الأطفال. وهذا ما يعطى للطفل الأول أهمية خاصة

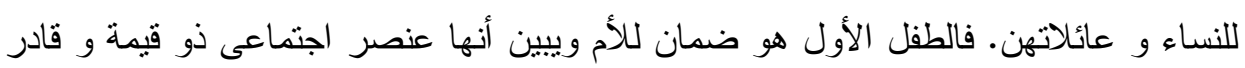

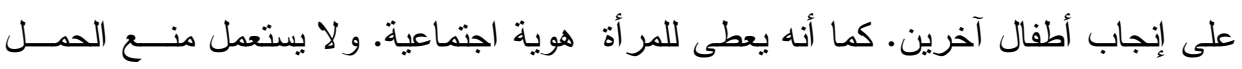

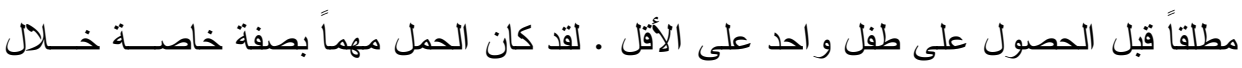

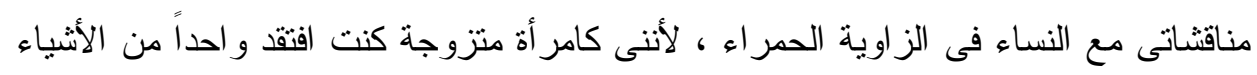

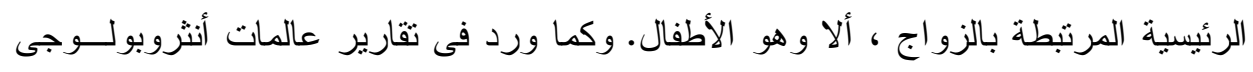

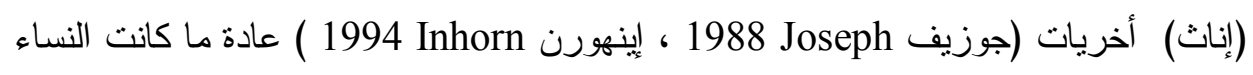
يضغطن عليهن من أجل إنجاب طفل مع تأكيد أن لهذا الأمر أولوية مقدمسـة عــن التعلــيم

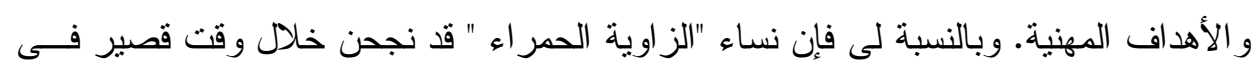

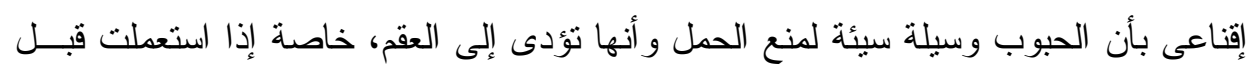

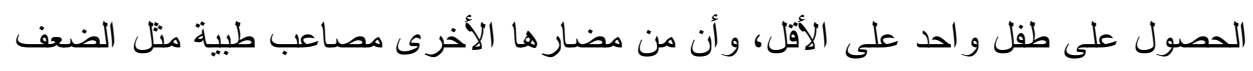
و وقدان الوزن. ثم حاولن إقتاعى بأن أذهب للطبيب لمعرفة ما إذا كنت فادرة على ملى الإنجــاب.

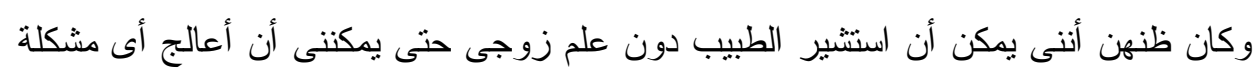

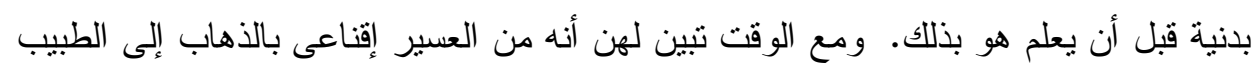

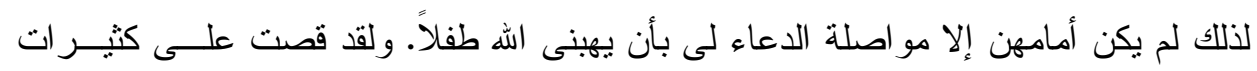

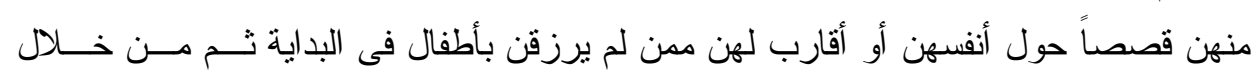
العلاج (الطبى أو التقليدى) رزقن بالعديد من الأطفال.

يعتقد فى "الز اوية الحمر اء " إن المشاعر الذاتية كما يعرضها أسلوب الجسد العاقل منل مشاعر

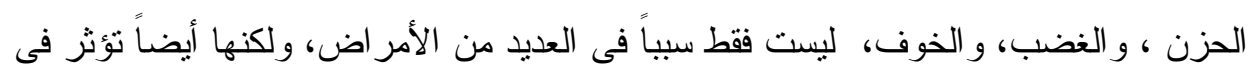
الوظائف الحيوية (البيولوجية) للجسم، ونتفى من العديد من المشاكل الصحية.

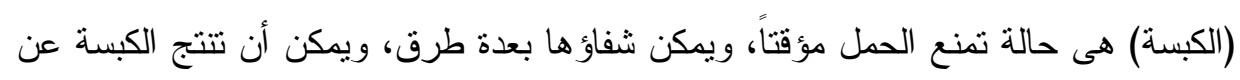

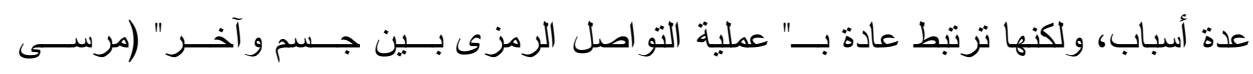

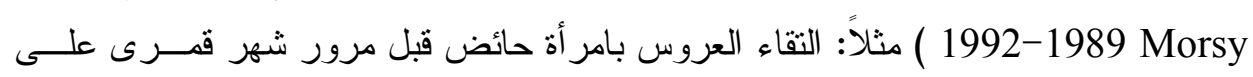

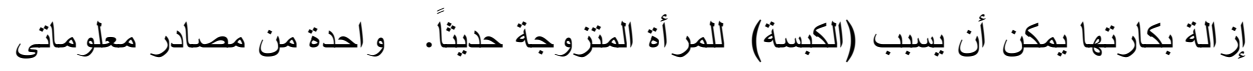

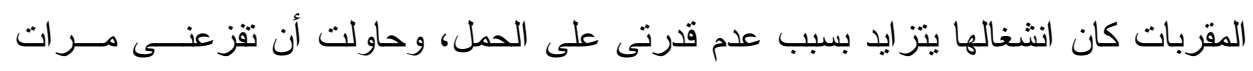

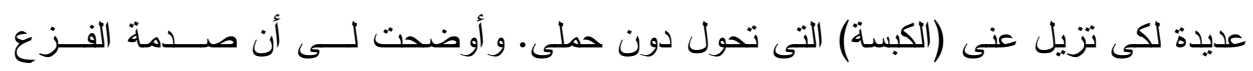

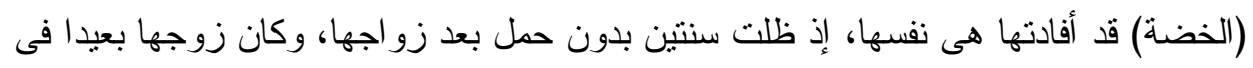

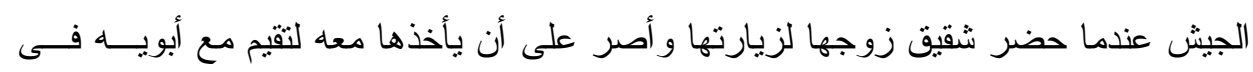

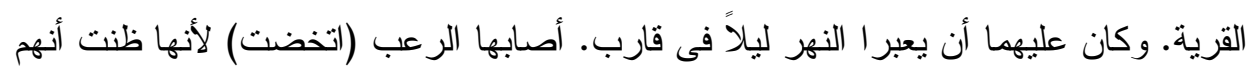




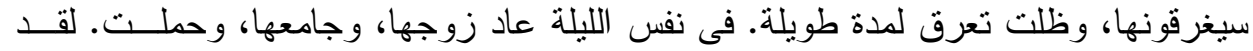

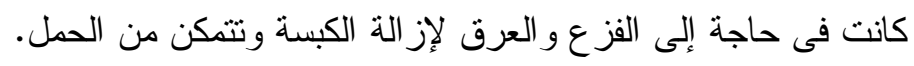

إن إظهار القدرة على الإنجاب تكتسب أهمية خاصة عندما تكون هنالك امر أة أخرى فى حيــاة

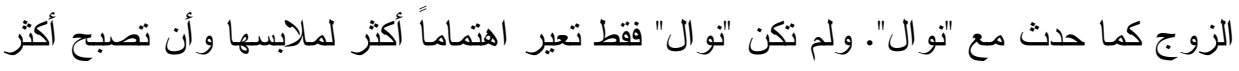

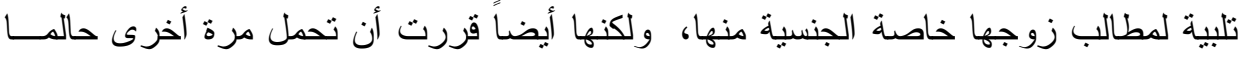

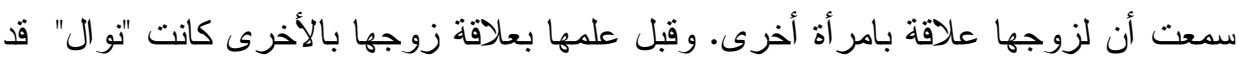

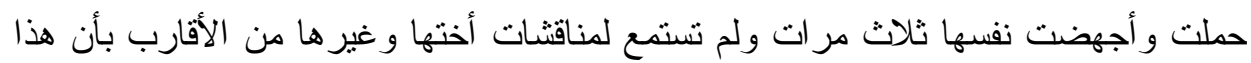
حر ام. وبحملها مرة أخرى و إنجابها للطفل الخامس، كانت تؤكد مرة أخرى لزوجها أنها قادرة على الإنجاب.

إن هذا التأكيد على الخصوبة هو إطار نظرة النساء وتفاعلاتهن نحو أجسامهن ومـشاكلهن

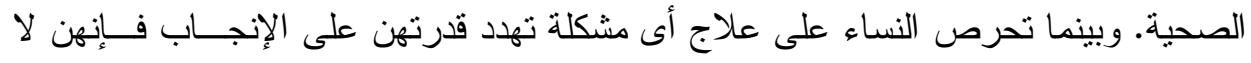

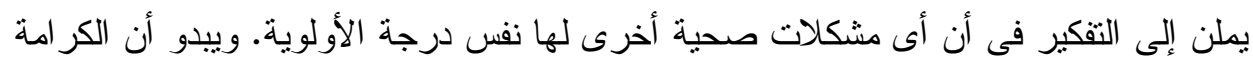

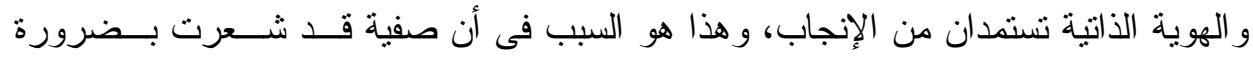

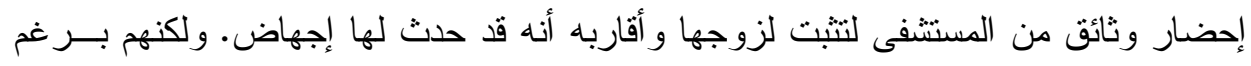

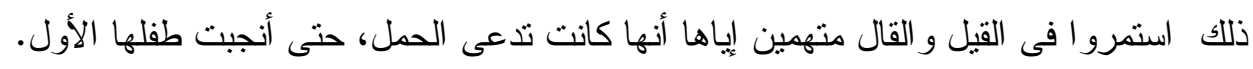

إن القيمة الاجتماعية الكبيرة للإنجاب ومركزيتها فى الحياة تؤطر (تصنع الإطـــار) الطريقــة التى تتظر بها النساء إلى أجسامهن و إلى صحتهن الإنجابية.

ب - الجسم الجميل هو الجسم الممتلىء: الطعام، المذاق، وجسم المرأة

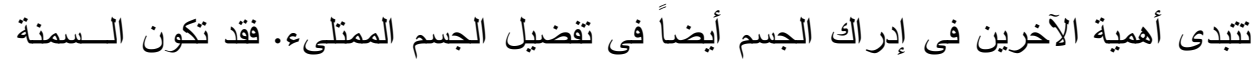
و النحافة هما أكثر الجو انب التى توضح كيف يمكن أن يعاد تتكيل الجسم لاصدلاح ما تتسبب فيه العو امل الاجتماعية ، وكيف أن الجسم مرتبط ارتباطاً وثثقاً بالهوية الذاتية. تقع النساء فى مختلف أنحاء العالم تحت ضغوط منضاربة لعرض أجسامهن وتشكيلها بطرق

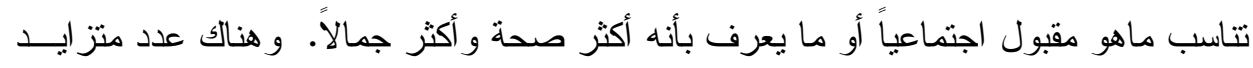

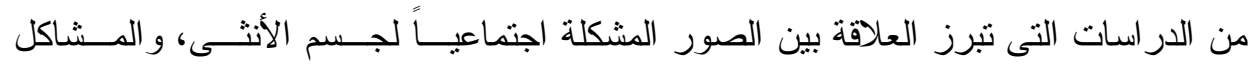

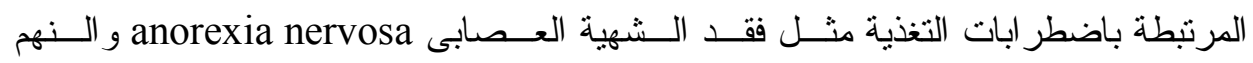
bulimia 
1992 Brenner and Cunningham 1991 Paxton and Sculthorpe . (1990 Morgan et al

| وتكثف در اسة الأمر اض فى الجيزة أن 43\% من النساء التى أجريت عليهن الدر اسة يعتبرن Formatted: Justified سمينات من وجهة النظر الطبية (زريق ومشاركوها Zurayk et al 1995 وكذلك يونس

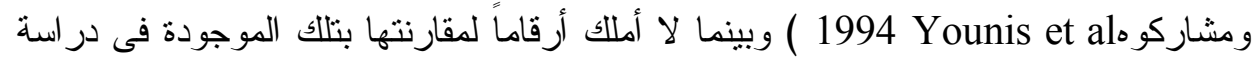
الجيزة، فإنه من الممكن القول طبقاً لما لاحظته أن الكثير ات من نساء الز اوية الحمر اء خاصة

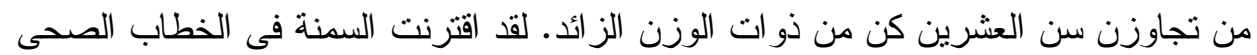
بمشكلات تتعلق بالخصوبة، و النوبات القلبية، وارتقاع ضغط الدم، و السكرى (السكر) (بونس

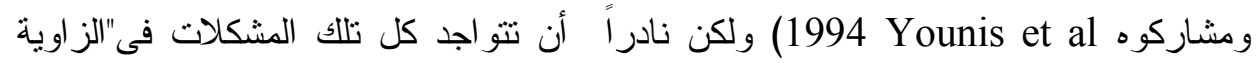

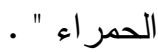

ففى الحقيقة برتبط الجسم الممتلىء أساساً بمعانى إيجابية توحى بالسعادة و الجمال و الجاذبيــة

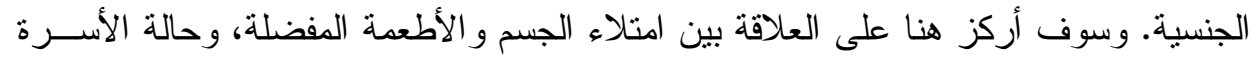

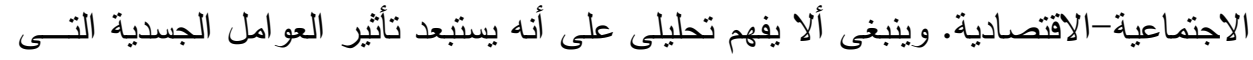
تغير الاستقلاب metabolism عند النساء مع مرور الوقت وتسبب زيــادة فــى أوز انهـن. ولكننى أريد أن أبين أن القيمة التى تختص بها أثنكال معينة للجسم تجرى صياغتها اجنماعياً، و هى وثيقة الصلة بمختلف الممارسات اليومية مثل شر اء الطعام و الطهى وتتاول الطعام.

لقد حلل بيير بورديو Pierre Bourdieu الجسم خلال عمله على أنه كيان مــادى، يـشكل

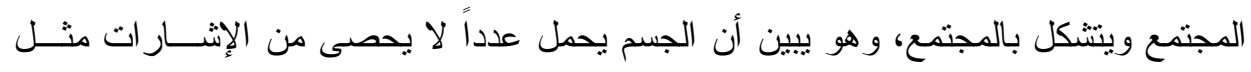

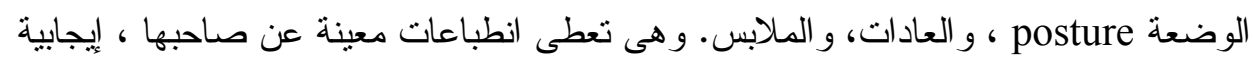
(الميل) أو سلبية (النفور) (بورديو 1984 Bourdieu). بهذا يكون الجسم هو الوسيط فـى لونى التفاعلات بين الناس ويعطى بيانات دلالية مختلفة عن صاحبه.

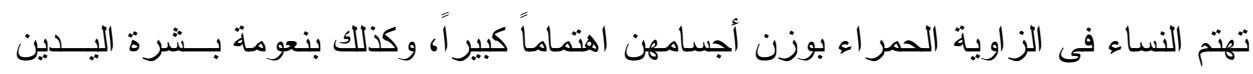

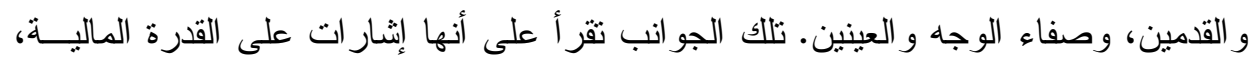

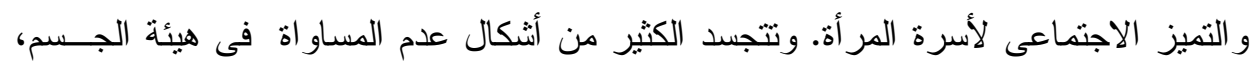

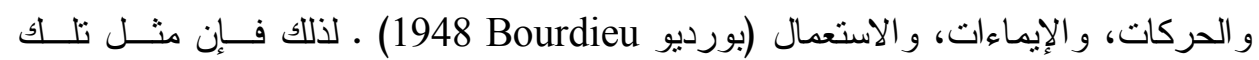


التجسيدات تعزز المعتقدات فى أن المسيطر هو " نظم التقسيم التى تجعلها تبدو كأنما هى نابعة

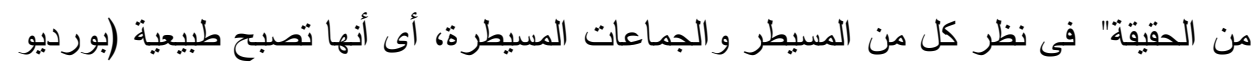
(1990 Bourdieu

ويبين بورديو 1984 Bourdieu) أن التوجهات حيال الملامح الجسدية تختلــــ اختلافــاً

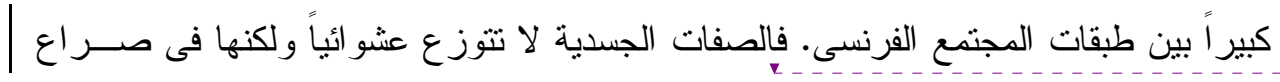

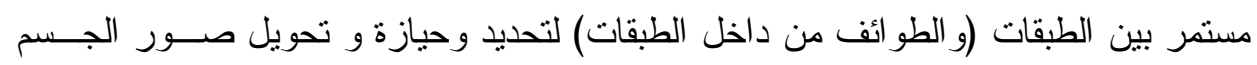

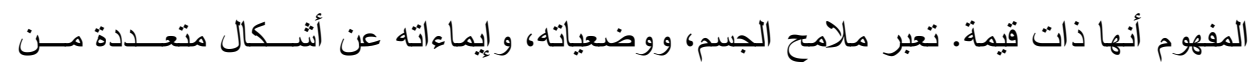

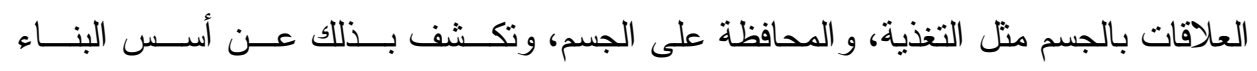

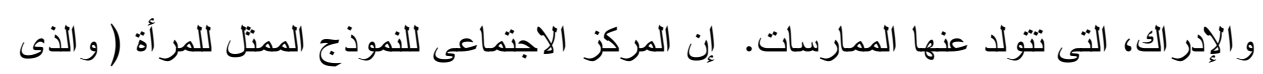

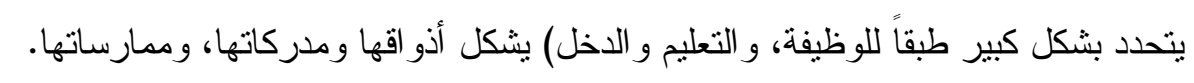

تعتمد أفضليات و اختيار الطعام على قوة الجسم، و الصحة و الجهــال (بورديـو Bourdieu

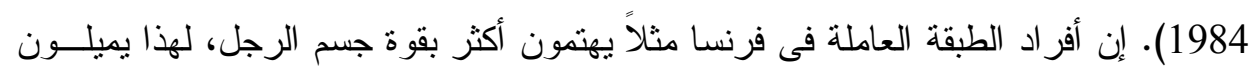

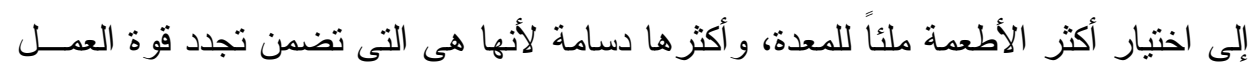

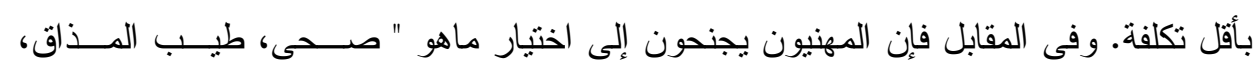

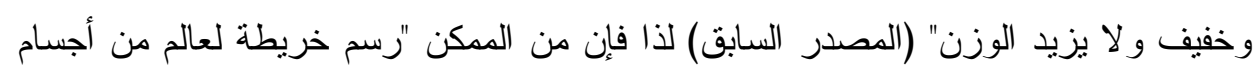

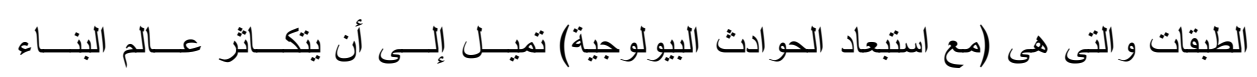
الاجتماعى طبقاً لمنطقها الخاص" (المصعدر السعاد السابق)

الناس فى "الز اوية الحمر اء " مثلهم مثل الطبقة العاملة فى "فرنــسـا " يميلـــون إلــى تقــضيل

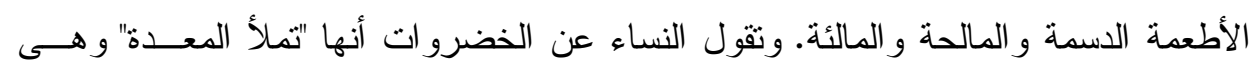

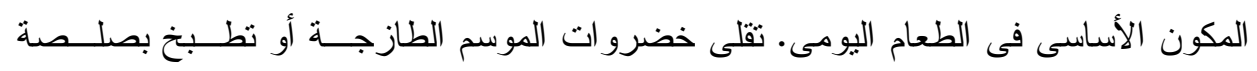

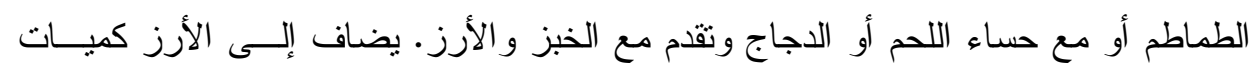

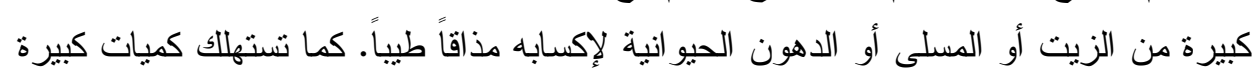

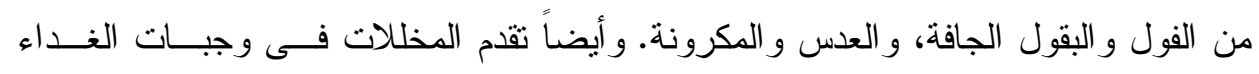

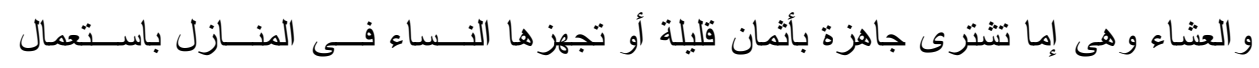

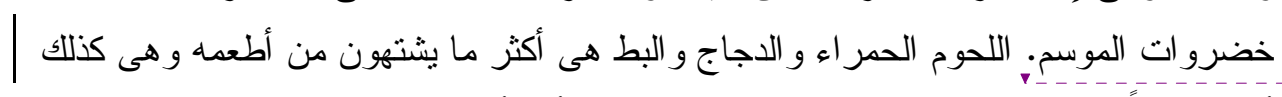

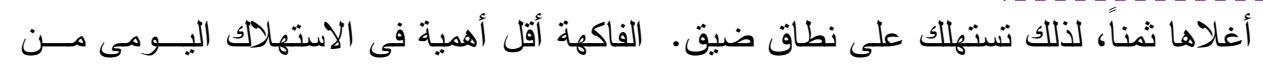




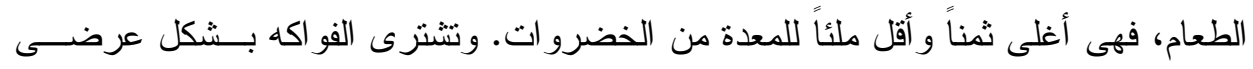
وتقدم للضيوف المميزين أو تقدم هدايا للمرضى أو عند زيارة الأصدقاء و الأقارب.

تصنف النساء الأطعمة وفقاً لإدر اكهن لفو ائدها للجسم، مثناً : فهن يعتقدن مــثلاً أن الــدجاج

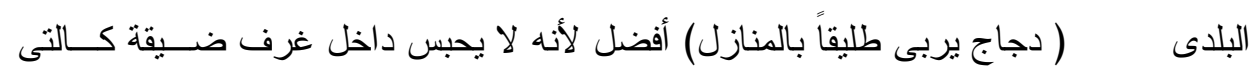

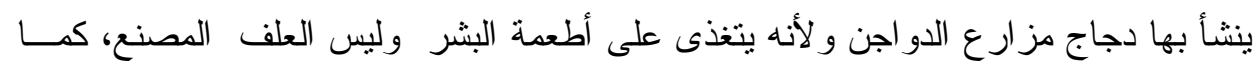

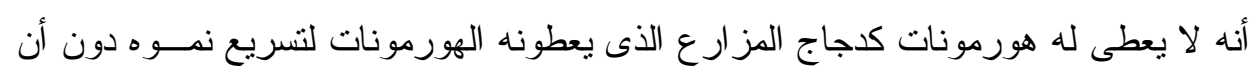

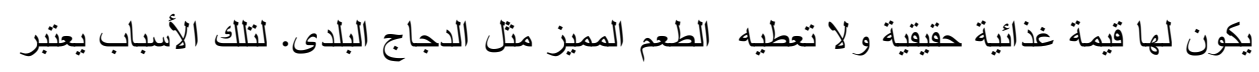

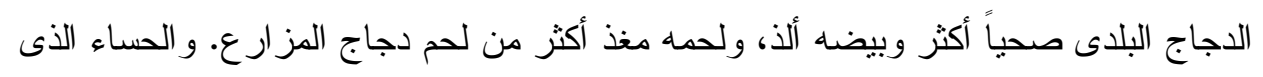

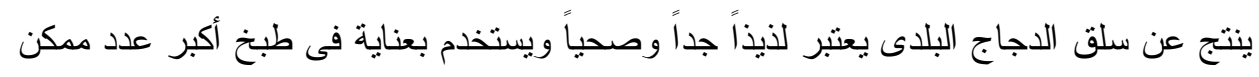

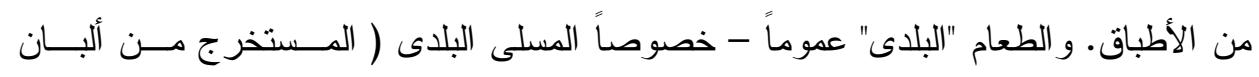

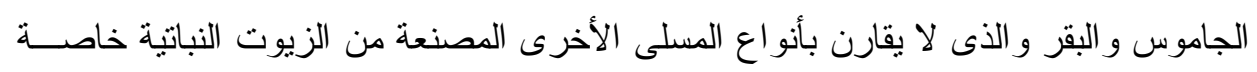

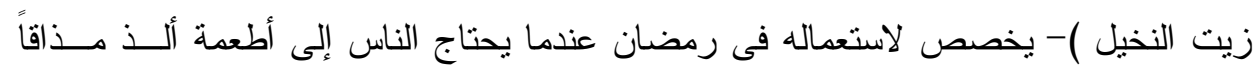

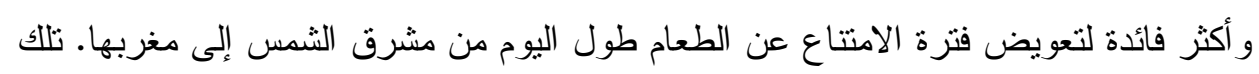

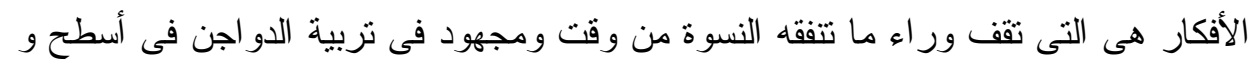
شرفات منازلهن، وتحت الأسرة، وفى عشش صغيرة أهُ أمام المبانى السكنية.

إن العلاقة بين الطعام المرغوب فيه و الجسم تتجلى فى سلوك الناس إز اء الحمل و أثز ها على إلى

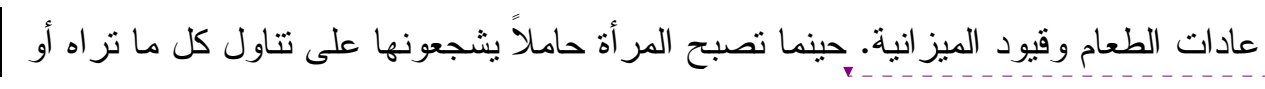

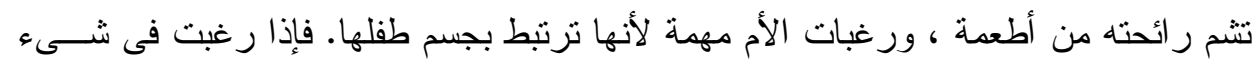
ولم تشبع رغبتها فسوف تظهر وحمة Birth mark)(عادة على شكل الطعام الذى اشتهته الأم

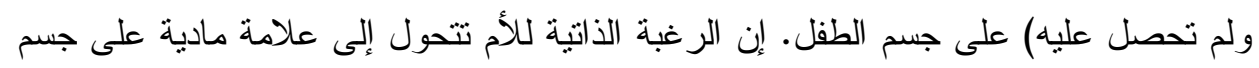
الجنين. وخلال الثهور القليلة الأولى للحمل تكون حالة الأم مميزة عن باقى فترات حياتها. إذ يمكنها

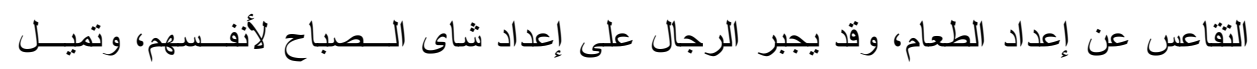

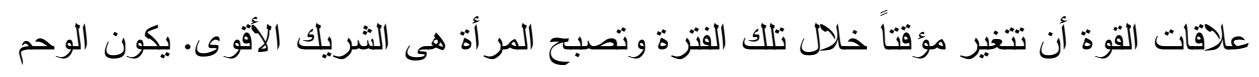
(craving)

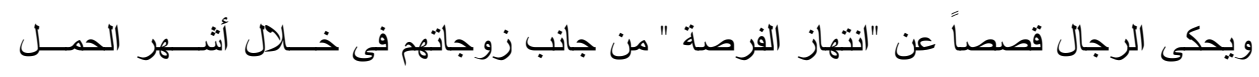

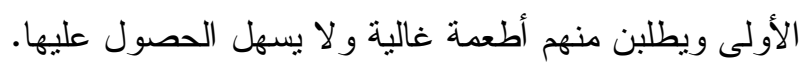


يتم تشجيع المر أة على نتاول كميات كبيرة من الأطعمة خلال أثنهر الحمل الأولـى "لأنهـن

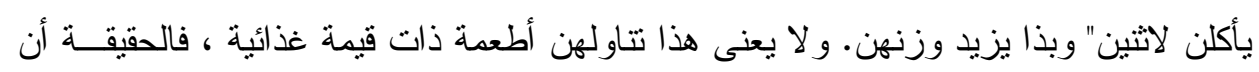

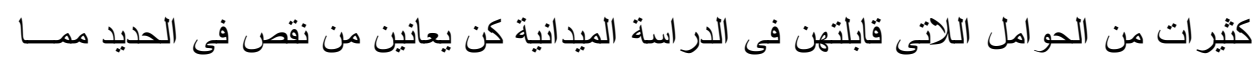

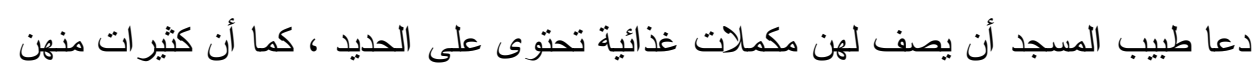

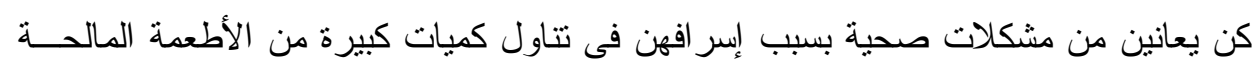

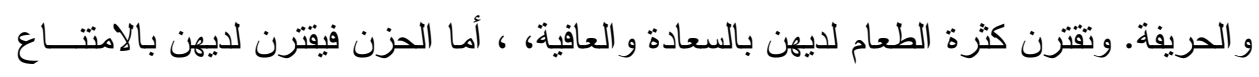

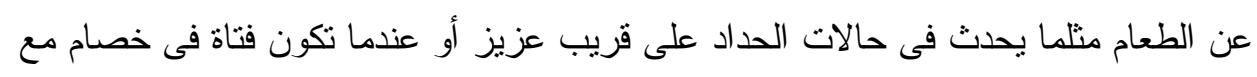
أهلها.

توجد علاقات قر ابة منتشابكة بين العقل و الطعام وشكل الجسم ـ فإذا كانت المر أة تأكل جيـــاً

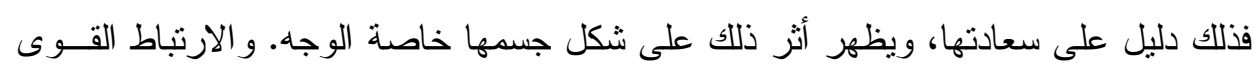

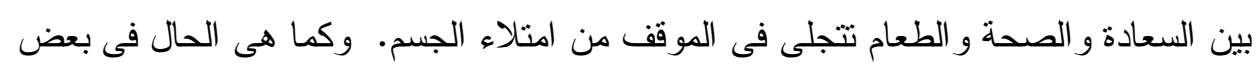

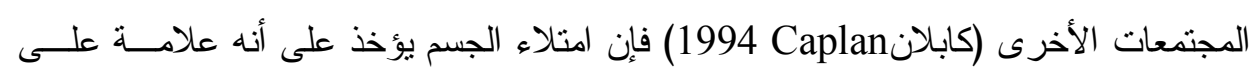

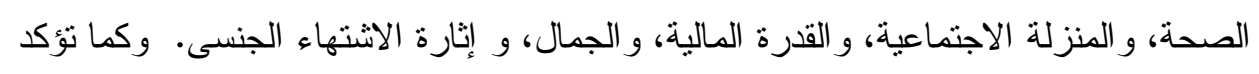
النساء فإن الرجال يفضلون الزوجات الممنلئات ويجدونهن أكثر جاذبية.

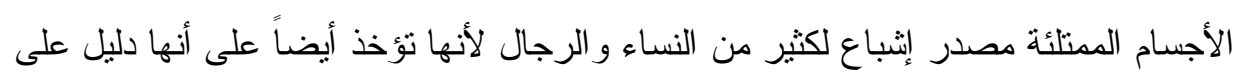

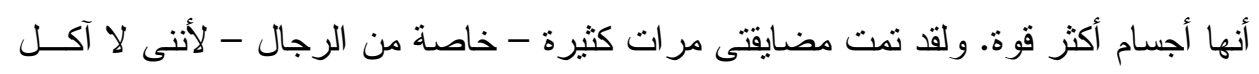

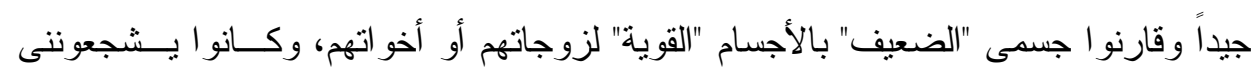

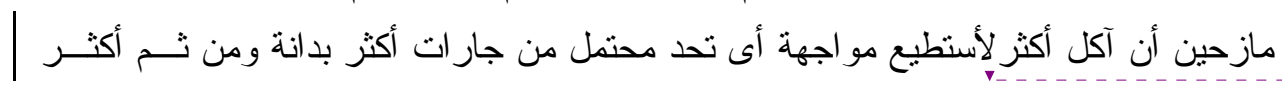
قوة. وتعتقد بعض النسوة أن الجسم السمين يعطيهن ميزة على نساء الطبقة العليا المــصرية و النساء الغربيات حيث الأجسام النحيفة هى المفضلة.

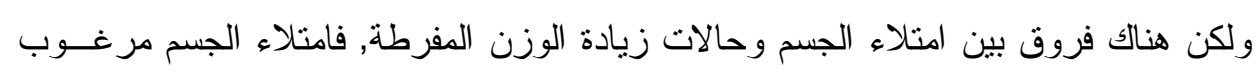

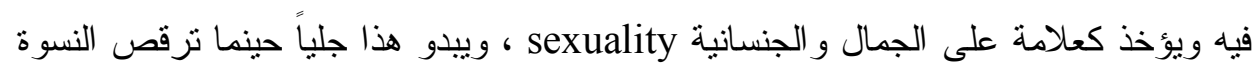

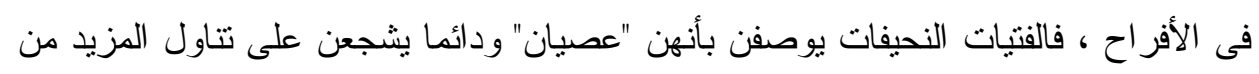

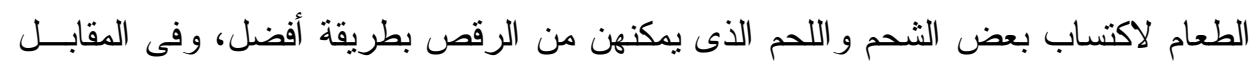

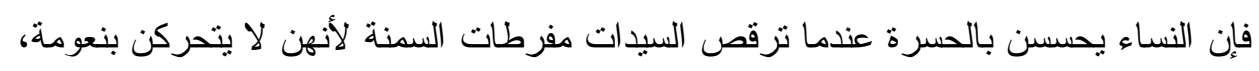

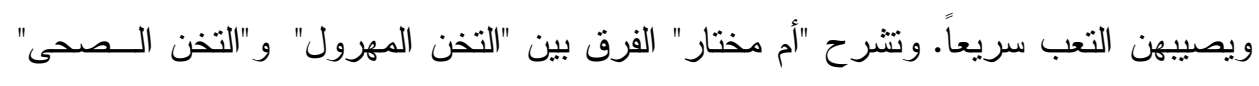

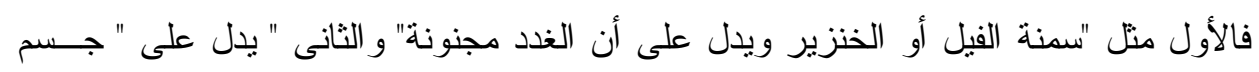

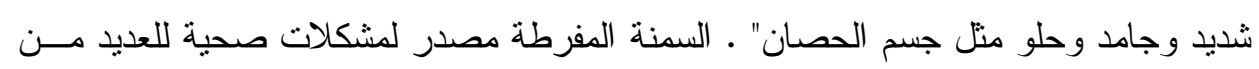


النساء ومن بين هؤلاء من ينصحه الأطباء بإنقاص الوزن فيو اجهن بقيود مختلفة، أهمهـــا أن

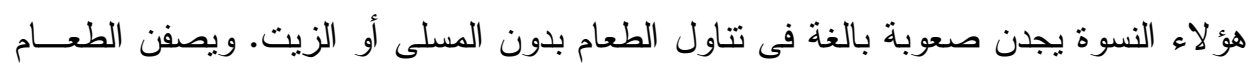

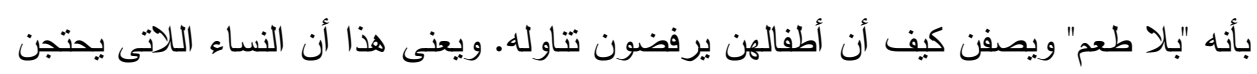

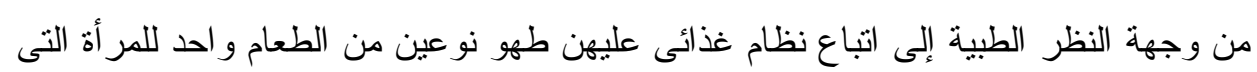

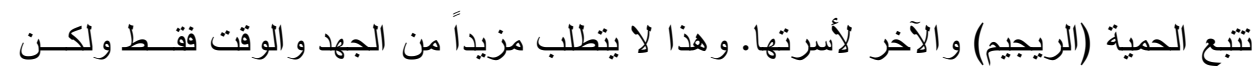

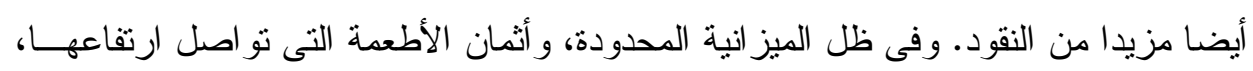

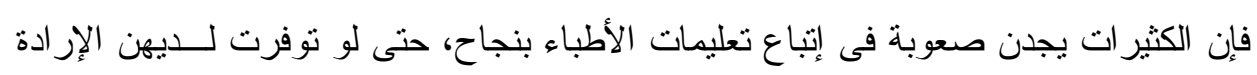
لذلك.

\section{- V}

قصدت من هذه الورقة أن ألفت الانتباه إلى أهمية إدر الك الجسد فى دراسة الصحة الإنجابيــة

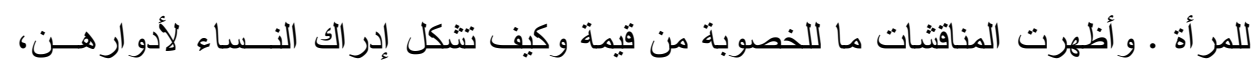

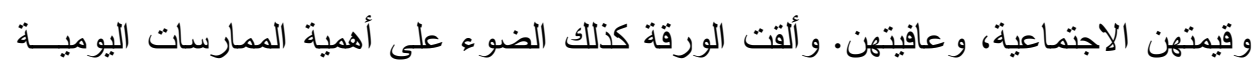

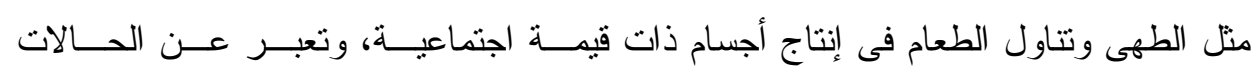

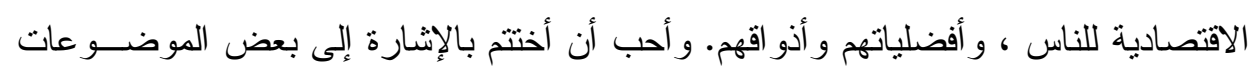

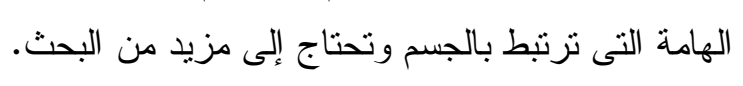

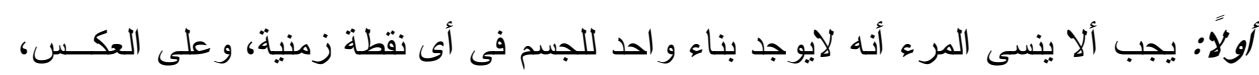

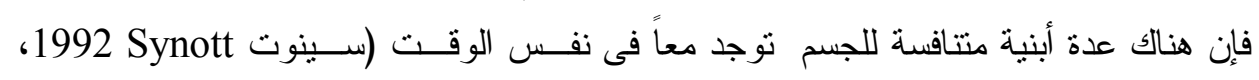

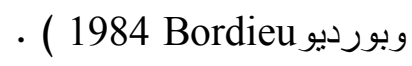
وفى الحقيقة فإن العولمة التقافية المتتامية تيسر تداول الرموز و الصور التــى تقــدم أفكـــارًا

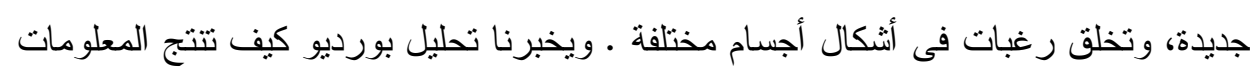
و التعليم اختلافات فى ثنايا الطبقة الو احدة.

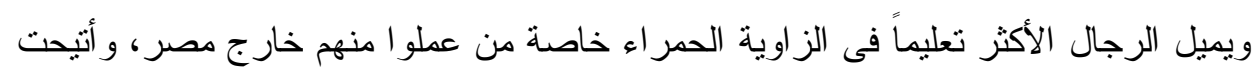

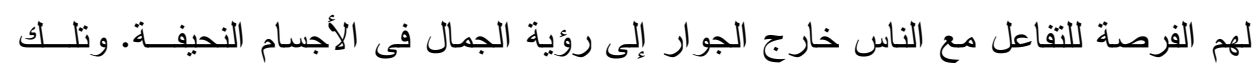

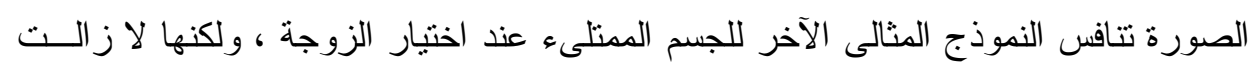

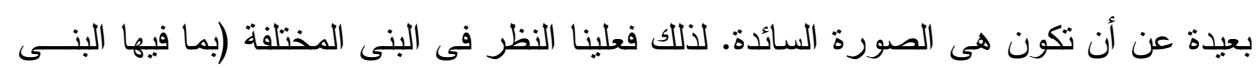
الطبية) للجسم. و اكتشاف كيف تم استحو اذها، ومقاومتها، وتحويلها بو اسطة النهاء النساء.

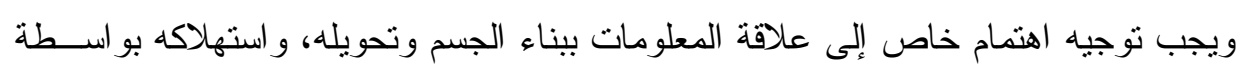
العملاء الاجتماعيين خاصة الثبان و الثابات. 
ثانيًا: إن النساء من خلال نفس الجيرة لسن جماعة متجانسة، ولكنهن يتفــرقن مــن حيــث

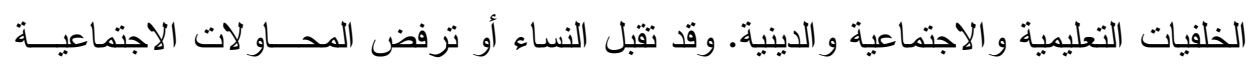

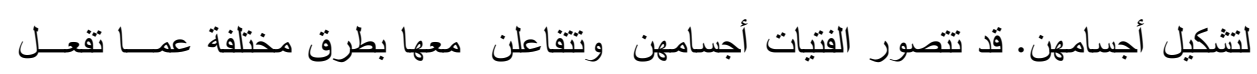

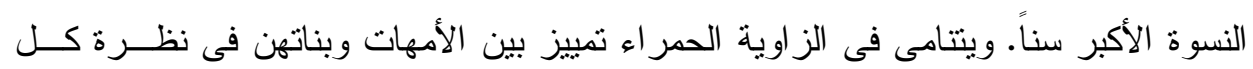
منهن للجسم الممتلىء. فالعديد من الثابات يرين أن النحافة علامة جمال، ويتبعن نظاماً غذائياً فى السر لتجنب المو اجهات مع أمهاتهن اللاتى يرين أن امتلاء الجسم هو الأكثر جمالاً مـن فئن النحافة.

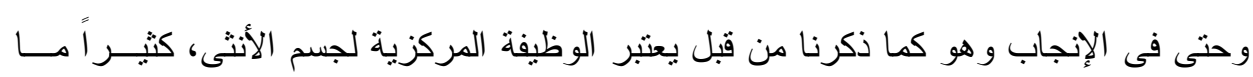

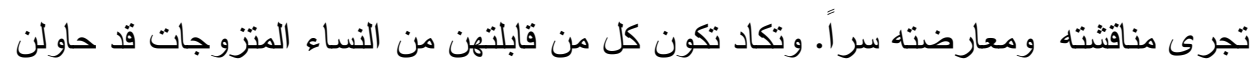

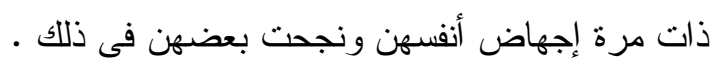

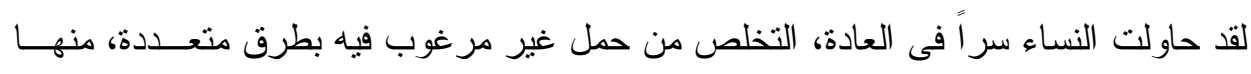

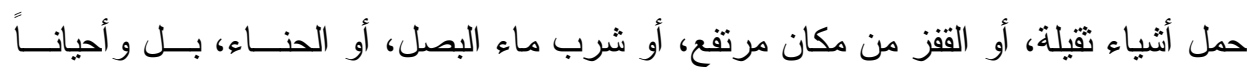

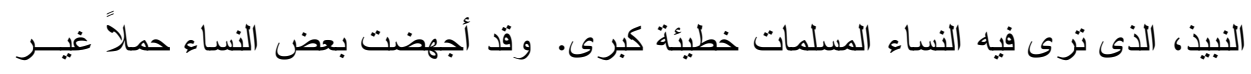

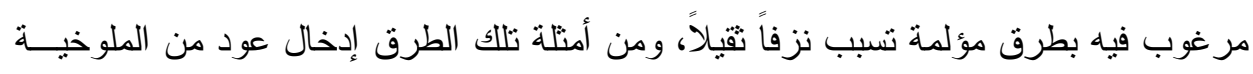

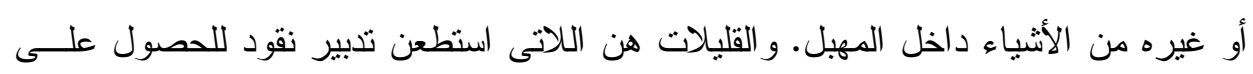
إجهاض بو اسطة مساعدة طبية. 5 .

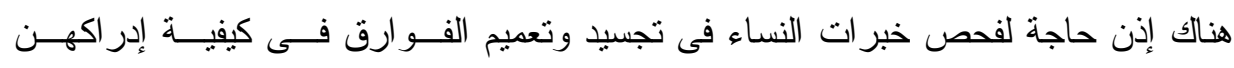
لأجسادهن.

ثالثا: على امتداد المناقثات السابقة أثنرت إلى كيف يتصور الرجال أجسام النساء ولكننى لم أناقش تللك النظرة. و هذا موضوع ذو أهمية خاصة، ويجب تقصيه بالتفصيل. إن فكرة الرجال

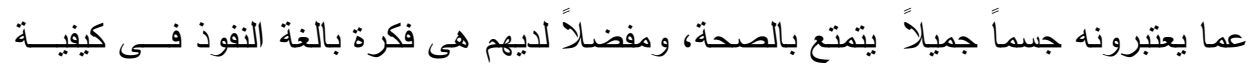
تصور النساء لأجسامهن و لأنفسهن.

رابعاً: كما أثنار فوكو Foucault فإنه يتوجب علينا در اسة الخطابات و الأماكن قوية التـأثنير فى صنع وتشكيل الجسم البشرى. 
المسجد مكان مشوق له تأثنير فى تشكيل أجسام نساء الزاوية الحمر اء فهو المكان الذى تدور

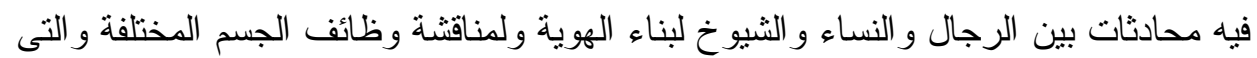

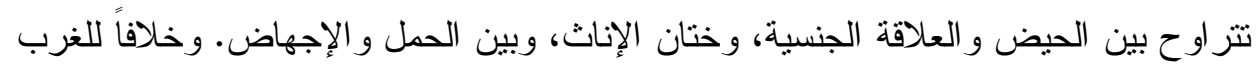

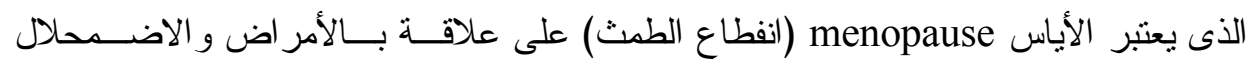

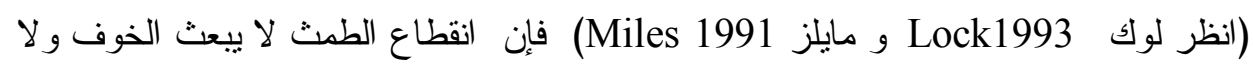
ينظر إليه نظرة سلبية فى الز اوية الحمر اء، بل فى الحقيقة يبدو أن النساء خاصة من لـألـيهن

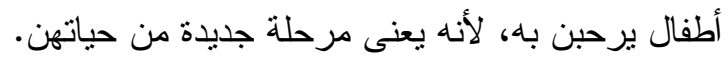

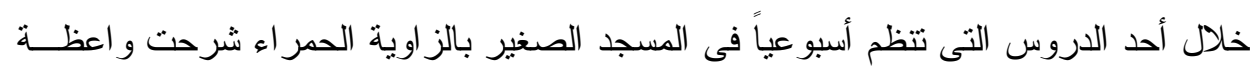

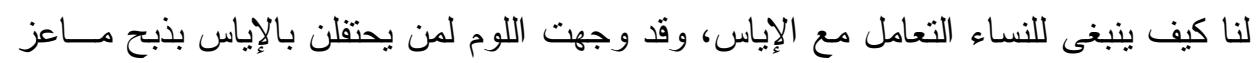

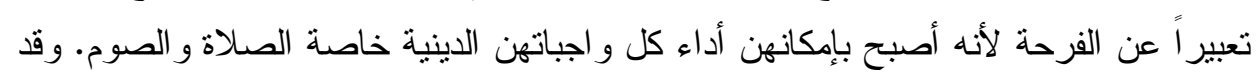

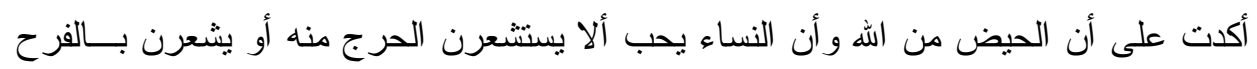
لانقطاعه. منل نللك المحاور ات تتجاور بطرق مختلفة فى إدر الك النساء لحقيقة أجسامهن.

بخامسًا : بالإضافة لار اسة تقديم الثقافات للجسم وفئات اللغويات التى نستعمل لتصنيف النوع، Formatted: Right و الفروق الجسدية، فإنه من الضرورى وضع المناقثنات حول الجسد وتكوينه فى سياق الحياة

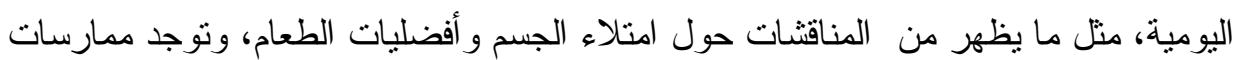
كثثرة يمكنها أن تؤثز فى الجسم وصحته، تشمل العمل، و الطهى، وتتاول الطعام، و التتظيف،

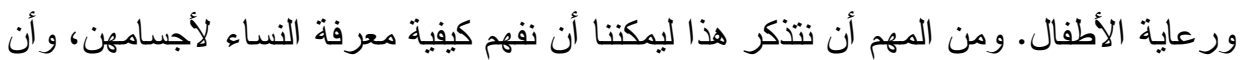

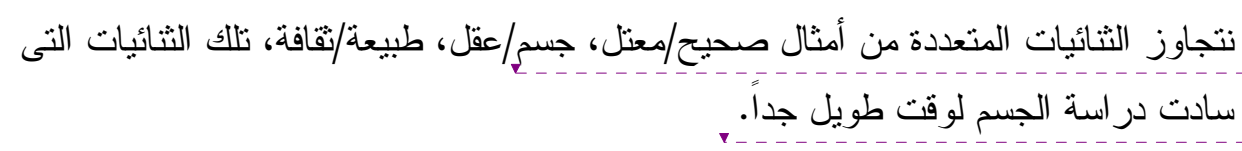

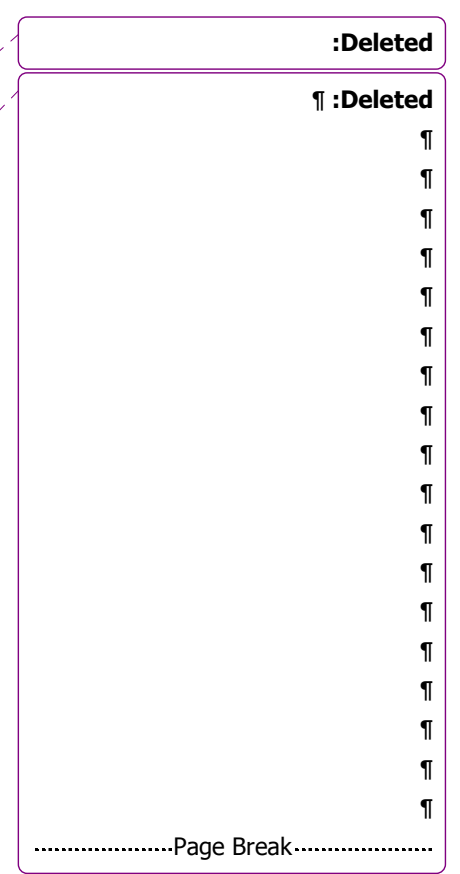

\section{References}

Abu-Lughod, Lila 1986 Veiled Sentiments: Honor and Poetry in a Bedouin Society. Berkeley: University of California Press.

Banks, Caroline Giles 1992 "'Culture ${ }^{1}$ in Culture-Bound Syndromes: The Case of Anorexia Nervosa," Social Science and Medicine, vol. 34, no. 8, Apr., pp. 867-884.

Berthelot, J.M. 1991 "Sociological Discourse and the Body," In The Body, Social Process and Cultural Theory, ed. by Mike Featherstone, Mike Hepworth and Brayn S. Turner. London: Sage Publications, pp. 390-405. 
Boddy, Janice 1988 "Spirits and Selves in Northern Sudan: The Cultural Therapeutics of Possession and Trance," American Ethnologist, vol. 15, pp.4-27.

Bordo, Susan 1989 "The Body and the Reproduction of Femininity: A Feminist Appropriation of Foucauit," In Gender/Body/Know ledge:

Fminist Reconstructions of Being and Knowing, ed. by Alison M. Taggar and Susan A. Borao. New BrunswicK: Autgers university Press.

Bourdieu, Pierre 1990 The Logic of Practice. Stanford: Stanford University Press.

Bourdieu, Pierre 1984 Distinction: A Social Critique of the Judgment of Taste. London: Routledge.

Bourdieu, Pierre 1977 Outline of a Theory of Practice. Cambridge: Cambridge University Press.

Brenner, Jennifer B., Cunningham, Joseph G. 1992 "Gender Differences in Eating Attitudes, Body Concept, and Self-Esteem among Models," Sex Rotes, vol. 27, no. 78, Oct., pp. 413-437.

Caplan, Pat 1994 Feats, Fasts, Famine: Food for Thought. Berg Occasional Papers in Anthropology, no. 2 London: Berg Publishers Ltd.

Doyal, Lesley 1995 What Makes Women Sick: Gender and the Political Economy of Health. New Brunswick: Rutgers University Press.

Dwyer, Daisy 1978 Images and Self-Images: Male and Female in Morocco. New York: Columbia University Press.

Duroche, Leonard 1990 "Male Perception as Social Construct," In Men, Masculinities and Social Theory, ed. by Jeff Hearn and David Morgan. London: Unwin Hyman Inc., pp. 170-186.

Featherstone, Mike 1991 "The Body in Consumer Culture," In The Body: Social Process and Cultural Theory, ed. by Mike Featherstone, Mike Hepworth, and Bryan Turner. London: SAGE Publications, pp. 170-196.

Foucault, Michel 1990(84; The Use of Pleasure. New York: Vintage Books.

Foucault, Michel 1980 The History of Sexuality. New York: Vintage books.

Foucauit, Michei 1979(77) Discipline and Punish: The Birth oj the Prison. New York: Vintage Books.

Frank, Arthur W. 1991 "For a Sociology of the Body: An Analytical Review," In The Body, Social Process and Cultural Theory, ed. by Mike Featherstone, Mike Hepworth and Brayn S. Turner. London: Sage Publications, pp. 36-102. 
Freund, Peter E. S. 1990 "The Expressive Body: A Common Ground for the Sociology of Emotions and Health and Illness," Sociology of Health and Illness, vol. 12, no. 4, pp. 452-477.

Goflman, Erving 1959 The Presentation of the Self in the Everyday Life. New York: Double Day Archer Books.

Good, Byron J. 1994 Medicine, Rationality, and Experience. Cambridge: Cambridge University Press.

Goudsmit, Ellen M. 1994 "All in Her Mind! Stereotypic Views and the Psychologisation of Women's Health," In Women and Health: Feminist Perspective, ed. by Sue Wilkinson and Celia Kitzinger. London: Taylor \& Francis Ltd., pp. 7-12.

Grosz, Elizabeth 1994 Volatile Bodies: Toward a Corporeal Feminism. Bloomington and Indianapolis: Indiana University Press.

Hesse-Biber, Sharlene 1991 "Women, Weight and Eating Disorders: A Socio-Cultural and Political Economic Analysis," Women's Studies International Forum, vol. 14, no. 3, pp. 173-191.

Joseph, Suad 1988 "Feminization, Familism, Self, and Politics: Research as a Mughtaribi," Arab Women in the Field, ed. by Soraya Altorki and Camillia Fawzi ElSolh. Cairo: The American University Press, pp. 25-48.

Kaplan, Gisela T. and Lesley J. Rogers 1990 "The Definition of Male and Female: Biological Reductionism and the Sanctions of Normality," in Feminist Knowledge: Critique and Construct, ed. by Sneja Gunew. London and New York: Routledge, pp. 205-228.

Khattab, Hind A. S. 1992 The Silent Endurance: Social Conditions of Women's Reproductive Health in Rural Egypt. Amman: UNICEF and the Population Council.

King, Ynestra 1989 "Healing the Wounds: Feminism, Ecology, and Nature/Culture Dualism," In Gender/Body/Knowledge: Feminist Construction of Being and Knowing, ed. by Alison M. Jaggar and Susan R. Bordo. New Brunswick and London: Rutgers University Press, pp. 115-141.

Krais, Beate 1993 "Gender and Symbolic Violence: Female Oppression in the Light of Pierre Bourdieu's Theory of Social Practice," In Bourdieu: Critical Perspectives, ed. by Craig Calhoun, Edward LiPuma, and Moishe Postone. Chicago: University of Chicago Press, pp. 156-177.

Inhorn, MarciaC. 1996 Infertility and Patriarchy: The Cultural Politics of Gender ond Familv in Egypt. Philadelphia: University of Pennsylvania.

Inborn, Marcia Claire 1994 Quest for Conception: Gender, Infertility, and Egyptian Medical Traditions. Philadelphia: University of Pennsylvania.

Lock, Margaret 1994 "The Politics of Mid-Life and Menopause: Ideologies for the Second Sex in North America and Japan," In Knowledge, Power, and Practice: The 
Anthropology of Medicine and Everyday Life, ed. by Shirley Lindenbaum and Margaret Lock. Berkeley: University of California Press, pp. 330-363.

MacLeod, Arlene Elowe 1991 Accommodating Protest: Working Women, the New Veiling, and Change in Cairo. Cairo: The American University in Cairo Press.

Martin, Emily 1992 (87) The Woman in the Body: A Cultural Analysis of Reproduction. Boston: Beacon.

Mernissi, Fatima 1987 Beyond the Veil: Male-Female Dynamics in Modern Muslim Society. Bloomington: Indian University Press.

Miles, Agnes 1991 Women, Health and Medicine. Miton Keynes: Open University Press.

Moore, Henrietta L. 1994 A Passion for Difference: Essays in Anthropology and Gender. Bloomington: Indiana University Press.

Morgan, Carolyn Stout; Affleck, Marilyn; Solloway, Grin 1990 "Gender Role Attitudes, Religiosity, and Food Behavior: Dieting and Bulimia in College Women," Social Science Quarterly, vol. 71, no. 1, Mar., pp. 142-151.

Morsy, Soheir 1980 "Body Concepts and Health Care: Illustrations from an Egyptian Village," Human Organization, vol. 39, no. 1, pp. 92-96.

Paxton, Susan J.; Sculthorpe, Anne 1991 "Disordered Eating and Sex Role Characteristics in Young Women: Implications for Sociocultural Theories of Disturbed Eating," Sex Roles, vol. 24, no. 9-10, May, pp. 587-598.

Oakley, Ann 1993 Women, Medicine and Health. Edinburgh: University Press. Ravindran, TKS. 1995 "Women's Health Policies: Organising for Change," Reproductive Health Matters, no. 6, pp. 7-11.

Rothfield, Philipa 1990 "Feminism, Subjectivity, and Sexual Experience," In Feminist Knowledge: Critique and Construct, ed. by Sneja Gunew. London and New York: Routledge, pp. 121-144.

Saltonstail, Robin 1993 "Healthy Bodies, Social Bodies: Men's and Women's Concepts and Practices of Health in Everyday Life," Social Science and Medicine, vol. 36, no. 1, pp. 7-14.

Shilling, Chris 1993 The Body and Social Theory. London: Sage Publications.

Synnott, Anthony 1993 The Body Social, Symbolism, Self and Society. London and New York: Routledge.

Synnott, Anthony 1992 "Tomb, Temple, Machine and Self: The Social Construction of the Body," British Journal of Sociology, vol. 43, issue 1, Mar., pp. 79-110. 
Turner, Bryan S. 1992 Regulating Bodies: Essays in Medical Anthropology. New York: Routledge.

Turner, Bryan S. 1991 "Review Article: Missing Bodies- Towards a sociology of embodiment," in Sociology of Health \& Illness, vol. 13, no. 2, pp. 265-272.

Turner, Bryan S. 199 la "Recent Developments in the Theory of the Body," In The Body, Social Process and Cultural Theory, ed. by Mike Featherstone, Mike Hepworth and Brayn S. Turner. London: Sage Publications, pp. 1-35.

Turner, Bryan S. 1984 The Body and Society, Explorations in Social Theory Oxford. Basil Black well.

Webb, Christine (ed.) 1986 Feminist Practice in Women's Health Care. Chichester: John Wiley \& Sons.

White, Jane H 1992 "Women and Eating Disorders, Part II: Developmental, Familial, and Biological Risk Factors," Health Care for Women International, vol. 13, no. 4, Oct-Dec, pp. 363-373.

Zurayk, Huda 1994 Women's Reproductive Health in the Arab World. Regional Paper no. 39. Cairo: The Population Council.

Zurayk, Huda, Nabil Younis, Hind Khattab 1995 "Rethinking Family Policy in Light of Reproductive Health Research," In Family, Gender, and Population in the Middle East, ed. by Carla Makhlouf Obermeyer. Cairo: The American University in Cairo Press, pp. 232-258.

Younis, Nabil, Karima Khalil, Huda Zurayk, and Hind Khattab 1994 Leaning about the Gynecological Health of Women. The Policy Series in Reproductive Health, no. 2. Cairo: The Population Council. 